\title{
Mercury methylation in high and low-sulphate impacted wetland ponds within the Prairie Pothole Region of North America
}

\author{
Cameron G.J. Hoggarth; Britt Dianne Hall, Ph.D.; \\ Carl P.J. Mitchell
}

\begin{abstract}
Version Post-print/accepted manuscript
Citation Hoggarth, C.G.J., Hall, B.D., Mitchell, C.P.J., 2015. Mercury

(published version) methylation in high and low-sulphate impacted wetland ponds within the prairie pothole region of North America. Environmental Pollution 205, 269-277. https://doi.org/10.1016/j.envpol.2015.05.046.
\end{abstract}

\section{Copyright/License}

(c) (1) $\odot$ This work is licensed under the Creative Commons

International License. To view a copy of this license, visit

http://creativecommons.org/licenses/by-nc-nd/4.0/.

How to cite TSpace items

\begin{abstract}
Always cite the published version, so the author(s) will receive recognition through services that track citation counts, e.g. Scopus. If you need to cite the page number of the author manuscript from TSpace because you cannot access the published version, then cite the TSpace version in addition to the published version using the permanent URI (handle) found on the record page.
\end{abstract}

This article was made openly accessible by $U$ of $T$ Faculty. Please tell us how this access benefits you. Your story matters. 


\section{Elsevier Editorial System(tm) for Environmental Pollution}

Manuscript Draft

Manuscript Number: ENVPOL-D-15-00088R1

Title: Mercury methylation in high and low-sulphate impacted wetland ponds within the Prairie Pothole Region of North America

Article Type: Research Paper

Keywords: methylmercury, sediment, surface water, sulphate, wetland ponds, North American Great Plains

Corresponding Author: Dr. Britt Dianne Hall, Ph.D.

Corresponding Author's Institution: University of Regina

First Author: Cameron G.J. Hoggarth

Order of Authors: Cameron G.J. Hoggarth; Britt Dianne Hall, Ph.D.; Carl P.J. Mitchell

Abstract: Using enriched stable $201 \mathrm{Hg}$ injections into intact sediment cores, we provide the first reported $\mathrm{Hg}$ methylation potential rate constants $(\mathrm{km})$ in prairie wetland ponds (0.016-0.17 d-1). Our $\mathrm{km}$ values were similar to other freshwater wetlands and did not differ in ponds categorized with high compared to low surface water concentrations of sulphate. Sites with high sulphate had higher proportions of MeHg in sediment (2.9 $\pm 1.6 \%$ vs. $1.0 \pm 0.3 \%)$ and higher surface water $\mathrm{MeHg}$ concentrations (1.96 $\pm 1.90 \mathrm{ng} \mathrm{L-1}$ vs. $0.56 \pm 0.55 \mathrm{ng} \mathrm{L}-1)$. Sediment-porewater partitioning coefficients were small, and likely due to high ionic activity. Our work suggests while $\mathrm{km}$ measurements are useful for understanding mercury cycling processes, they are less important than surface water MeHg concentrations for assessing MeHg risks to biota. Significant differences in $\mathrm{MeHg}$ concentrations between sites with high and low sulphate concentrations may also inform management decisions concerning wetland remediation and creation. 


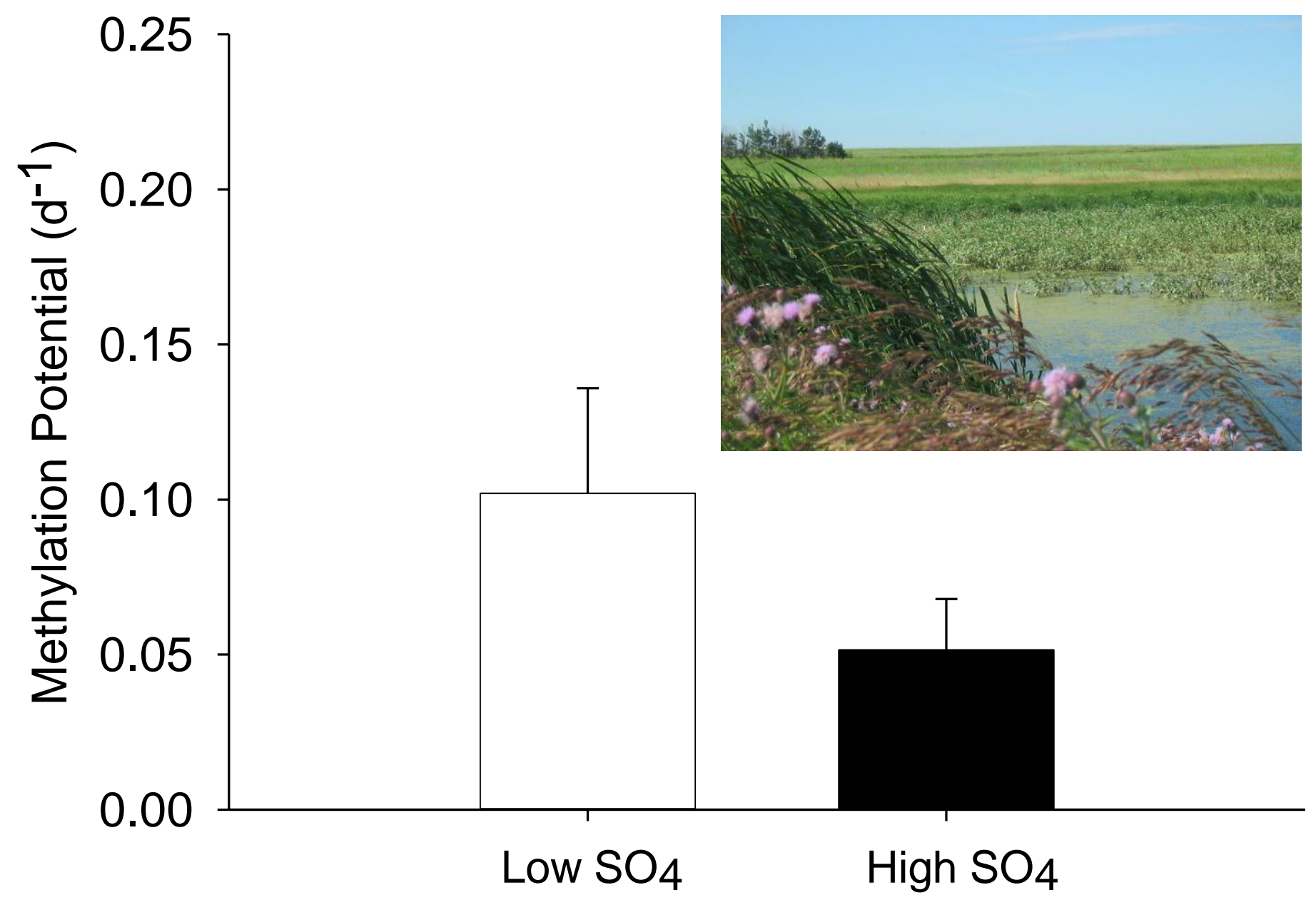


- Wetlands of the PPR provide many vital ecosystem services, but can have high $\mathrm{MeHg}$ concentrations

- Methylation potentials in prairie ponds are similar to other freshwater wetlands

- $\mathrm{MeHg}$ and \% MeHg in surface water of high sulphate ponds was greater than low sulphate ponds

- Sediment-porewater partitioning coefficients were small compared to other systems

- Potential methylation rate constants did not correlate to surface water concentrations 
1 Mercury methylation in high and low-sulphate impacted wetland ponds within the Prairie

2 Pothole Region of North America

3 Cameron G.J. Hoggarth ${ }^{1}$, Britt D. Hall ${ }^{1 *}$, and Carl P.J. Mitchell ${ }^{2}$

$4 \quad{ }^{1}$ Department of Biology, University of Regina, 3737 Wascana Parkway, Regina, SK, Canada 5 S4S 0A2

$6 \quad{ }^{2}$ Department of Physical and Environmental Science, University of Toronto Scarborough, 1265

7 Military Trail, Toronto, ON, Canada M1C 1A4

$8 *$ *corresponding author: Telephone (306) 337-2355, Fax (306) 337-2410, britt.hall@uregina.ca

9 Keywords: methylmercury, sediment, surface water, sulphate, wetland ponds, North American

10 Great Plains

11 Capsule: Prairie wetland ponds with higher sulphate concentrations have greater sediment and

12 surface water methylmercury concentrations, but potential methylation rates do not differ.

13 ABSTRACT

14 Using enriched stable ${ }^{201} \mathrm{Hg}$ injections into intact sediment cores, we provide the first reported $15 \mathrm{Hg}$ methylation potential rate constants $\left(k_{m}\right)$ in prairie wetland ponds $\left(0.016-0.17 \mathrm{~d}^{-1}\right)$. Our $k_{m}$ 16 values were similar to other freshwater wetlands and did not differ in ponds categorized with

17 high compared to low surface water concentrations of sulphate. Sites with high sulphate had

18 higher proportions of $\mathrm{MeHg}$ in sediment (2.9 $\pm 1.6 \% v s .1 .0 \pm 0.3 \%)$ and higher surface water

19 MeHg concentrations $\left(1.96 \pm 1.90 \mathrm{ng} \mathrm{L}^{-1}\right.$ vs. $\left.0.56 \pm 0.55 \mathrm{ng} \mathrm{L}^{-1}\right)$. Sediment-porewater

20 partitioning coefficients were small, and likely due to high ionic activity. Our work suggests

21 while $k_{m}$ measurements are useful for understanding mercury cycling processes, they are less

22 important than surface water $\mathrm{MeHg}$ concentrations for assessing $\mathrm{MeHg}$ risks to biota.

23 Significant differences in $\mathrm{MeHg}$ concentrations between sites with high and low sulphate

24 concentrations may also inform management decisions concerning wetland remediation and 25 creation.

\section{INTRODUCTION}

27 Methylmercury ( $\mathrm{MeHg}$ ) is a neurotoxin produced via microbial activity of a range of 28 microbes including sulphate reducing bacteria (SRB), iron reducing bacteria, and methanogens 
29 in wetlands and aquatic sediment. Methylmercury production rates depends on both availability

30 of inorganic mercury $(\mathrm{Hg})$ to, and metabolic activity of, methylating organisms (Hintelmann

31 2010). Thus, factors that influence $\mathrm{Hg}$ bioavailability (such as $\mathrm{pH}$ (Kelly et al. 2003) and

32 sulphur speciation (Benoit et al. 1999)) and the activity of both methylating and demethylating

33 bacteria (such as temperature (Loseto et al. 2004) and organic matter lability (Mitchell et al.

34 2008)) control net MeHg production rates. Sediment MeHg can be taken up by benthic

35 invertebrates or diffused to surface water, and made available to pelagic organisms, ultimately

36 bioaccumulating in fish. In small, depressional wetland ponds that do not support fish

37 communities, such as those in the prairie region, benthic invertebrates may be important vectors

38 of MeHg to terrestrial organisms such as insectivorous birds (Bates and Hall 2012). Overall, net

$39 \mathrm{MeHg}$ production (rate of $\mathrm{Hg}$ methylation less the rate of $\mathrm{MeHg}$ demethylation) in sediments can

40 ultimately result in biomagnification in aquatic food webs and thus harmful effects to humans

41 and wildlife (Mergler et al. 2007; Scheuhammer et al. 2007).

42 Wetlands have been identified as important sites of net $\mathrm{MeHg}$ production and $\mathrm{MeHg}$ sources

43 to downstream systems (St. Louis et al. 1994), but there is significant variability in $\mathrm{Hg}$

44 methylation among different wetland types. The Prairie Pothole Region (PPR) of the North

45 American Great Plains extends over 850,000 $\mathrm{km}^{2}$ and holds $\sim 5-8$ million small, depressional

46 wetland ponds (Johnson et al. 2010). A wide range of hydrologic (permanent water to seasonal

47 drying) and chemical variability (e.g. electrical conductivity, $\mathrm{pH}$, dissolved organic carbon

48 [DOC] concentrations) combined with shallow ponds and warm temperatures, may result in high

$49 \mathrm{MeHg}$ production rates in these systems. Concentrations of $\mathrm{MeHg}$ are elevated in surface water

50 and sediment of some prairie wetlands in Saskatchewan and North Dakota (Hall et al. 2009;

51 Sando et al. 2007), suggesting substantial net production of $\mathrm{MeHg}$.

52 Many wetlands and lakes within the PPR are saline, with high sulphate concentrations,

53 although significant spatial and temporal chemical variability has been observed across the

54 region (Last, 1999). The PPR is underlain by pyrite-rich sediment; the weathering and oxidation

55 of pyrite, climatic factors, and groundwater dynamics are responsible for observed high sulphate

56 concentrations (Goldhaber et al. 2014). Sulphur isotopes also show strong support for microbial

57 sulphate reduction within this system (Goldhaber et al. 2014). The possible stimulative or

58 inhibitive links between sulphate dynamics and $\mathrm{MeHg}$ production have not been explored in the

59 PPR, however in other wetland systems impacted by sulphate such as the Florida Everglades, 
$60 \mathrm{MeHg}$ production is greatest at low to moderate sulphate concentrations $\left(2-20 \mathrm{mg} \mathrm{L}^{-1}\right)$ with 61 moderate pore water sulphide concentrations (5-150 $\mathrm{g} \mathrm{L}^{-1}$; Gilmour et al. 1998, Axelrad et al.

62 2007). Very low sulphate concentrations are unsupportive for the SRB responsible for most $\mathrm{Hg}$

63 methylation, whereas high sulphate concentrations may lead to high sulphide concentrations,

64 which reduce the bioavailability of $\mathrm{Hg}$ for methylation (Benoit et al. 2003). Thus, the balance

65 between bacterial stimulation and reduced $\mathrm{Hg}$ bioavailability is an important aspect of the

66 sulphate-Hg methylation dynamic.

67 No investigations of in situ $\mathrm{Hg}$ methylation in prairie sediment, likely the principal source of

$68 \mathrm{MeHg}$ to these ecosystems, have been done. Our primary objective was to measure $\mathrm{Hg}$

69 methylation potential rate constants wetland sediment from the PPR; measurements that have

70 previously been made in sediment from aquatic systems including freshwater (Lehnherr et al.

71 2012b) and saltwater wetlands (Mitchell and Gilmour 2008), streams, lakes (Gentès et al. 2013),

72 and marine sediment (Hammerschmidt and Fitzgerald 2004). A secondary objective was to

73 investigate the role of surface water sulphate concentrations on $\mathrm{Hg}$ methylation potentials and

$74 \mathrm{MeHg}$ and $\mathrm{THg}$ concentrations in prairie wetland ponds. This study is the first to report $\mathrm{Hg}$

75 methylation potential rate constants in prairie region wetland sediment. Furthering our

76 understanding of $\mathrm{MeHg}$ production and $\mathrm{Hg}$ accumulation in wildlife is paramount to adequately

77 evaluating ecotoxicological risk in this valuable ecosystem, which is estimated to contain habitat

78 for over $80 \%$ of migrating North American waterfowl (Batt et al. 1989).

79 METHODS

80 Study Site

81 Sediment and water were collected from nine prairie wetland ponds within Saskatchewan's

82 St. Denis National Wildlife Area (SDNWA; Fig. S1; Table S1). The 361 hectare SDNWA is

83 located $\sim 40 \mathrm{~km}$ east of Saskatoon and is comprised of areas of cultivated annual crops, perennial

84 grass, and birch and willow that surround many wetland ponds (Pennock et al. 2010). This region

85 has a humid continental climate with daily mean temperatures from $1971-2000$ of $2.2^{\circ} \mathrm{C}$; ranging

86 from $-17.0^{\circ} \mathrm{C}$ in January to $+18.2^{\circ} \mathrm{C}$ in July, with daily mean temperatures $>0{ }^{\circ} \mathrm{C}$ from April

87 through October. Over the same period, mean annual precipitation was $350 \mathrm{~mm}$ with 25\% as

88 snowfall. 
Within the SDNWA, four wetland ponds (Ponds 2, 3, 130, and 139) were located in a

90 lowland area that forms a ring at the base of an upland area 5 to $10 \mathrm{~m}$ above. Five wetland ponds

91 located in upland areas (Ponds 100, 103, 110, 113, and 118) were also sampled. Our grouping of

92 wetland ponds was originally based on topographic position, but this delineation also falls along

93 distinct differences in surface water sulphate concentration. Upland wetland ponds were

94 characterized by surface water sulphate concentrations lower than $20 \mathrm{mg} \mathrm{L}^{-1}$ (henceforth "Low

$95 \mathrm{SO}_{4}$ "), whereas lowland wetland ponds had sulphate concentrations between 150 and $3250 \mathrm{mg} \mathrm{L}^{-}$

$96{ }^{1}$ (henceforth "High $\mathrm{SO}_{4}$ "). These sulphate groupings provide a clear comparison with previous

97 work where our "Low SO4" sites coincide with sulphate concentrations expected to stimulate

$98 \mathrm{MeHg}$ production and our "High SO4" sites coincide with sulphate concentrations expected to

99 reduce $\mathrm{Hg}$ bioavailability for methylation (Benoit et al. 2003; Axelrad et al. 2007). The High

$100 \mathrm{SO}_{4}$ ponds tended to have significant riparian vegetation and duckweed (Lemnoideae)

101 communities. All wetlands studied were classified as shallow, Type III marshes which are

102 seasonally flooded (Stewart and Kantrud 1971; additional details in supplemental section).

103 Depending on annual and summer precipitation, timing of spring snow melt, and temperature

104 patterns, it is typical that these wetland ponds dry completely by the end of the growing season;

105 most likely due to infiltration to shallow groundwater and evapotranspiration (Hayashi et al.

106 1998; Nachson et al. 2014). However, during our study period none of the ponds completely

107 dried up (Table S1).

\section{Sample Collection}

109 Sediment Sampling and Isotope Incubations

110 Wetland sediment cores were collected in July and August 2011 and analyzed for total $\mathrm{Hg}$ $111(\mathrm{THg})$ and $\mathrm{MeHg}$ concentrations and organic matter content (\%OM; Heiri et al. 2001 and 112 supplemental information). Core tubes were $30 \mathrm{~cm}$ long, $5 \mathrm{~cm}$ diameter acrylic cylinders with a 113 beveled bottom edge and 1/16" silicone-sealed septa spaced $1 \mathrm{~cm}$ apart in a column down the 114 side of the cylinder. Three cores at each wetland pond were taken 1-3 m apart from sediment 115 submerged in 5-25 $\mathrm{cm}$ of water. All cores had an organic sediment layer of at least $9 \mathrm{~cm}$. Cores 116 with thick roots or more than $3 \mathrm{~cm}$ of sediment compression were discarded. Patches of dense 117 vegetation and disturbed areas were avoided. In July 2011 only, we measured potential 118 methylation rate constants in six wetland cores using standard enriched stable $\mathrm{Hg}$ isotope 
119 techniques (Mitchell and Gilmour 2008; Lehnherr et al. 2012b). $100 \mu \mathrm{lof}$ an $\sim 4 \mathrm{~g} \mathrm{~mL}^{-1}$

120 solution of $96.17 \%$ enriched ${ }^{201} \mathrm{Hg}$ was injected, using a gas-tight borosilicate glass syringe and

121 stainless steel needle, through each of the septa within the top $10 \mathrm{~cm}$ of each core. The injected

122 solution was prepared using a ${ }^{201} \mathrm{HgCl}$ stock solution equilibrated for 1-2 hours with native pore

123 water. The intended amount of $\mathrm{Hg}$ injected into cores was less than double the $\mathrm{THg}$ in sediment.

124 Direct analyses of THg isotope in sediment indicated that $\mathrm{Hg}$ contents were increased by 8-66\%

125 of the ambient $\mathrm{THg}$. After injection of the enriched $\mathrm{Hg}$ isotope solution, cores were incubated at

126 ambient field temperature (mean $19.6^{\circ} \mathrm{C}$; range $=17-22^{\circ} \mathrm{C}$ ) for 4 hours, then sectioned into $2 \mathrm{~cm}$

127 sections, placed in $120 \mathrm{ml}$ polypropylene containers, frozen on dry ice, and subsequently freeze

128 dried and homogenized.

129 Water Sampling

130 Porewater was sampled for $\mathrm{THg}, \mathrm{MeHg}$, DOC and sulphate concentrations, $\mathrm{pH}$, and

131 electrical conductivity. The day before the incubations a 10-cm diameter acrylic core tube was

132 used to create 10-20 $\mathrm{cm}$ deep holes adjacent to the core sampling areas. Sampling holes were

133 left overnight to allow water to accumulate and sediment particles to settle. Porewater samples

134 were then taken from approximately 1-2 $\mathrm{cm}$ below the accumulated water surface using a

135 peristaltic pump outfitted with acid-washed Teflon sample tubing and dispensed into pre-cleaned

$136125 \mathrm{~mL}$ glass bottles with fluoropolymer resin lined lids. Using ultraclean handling techniques,

137 a perfluoroalkoxy filter cartridge containing an ashed $47 \mathrm{~mm}, 45 \mu \mathrm{m}$ Whatman quartz fibre filter,

138 was used to filter porewater collected for $\mathrm{THg}$ and $\mathrm{MeHg}$ concentrations. Samples for porewater

$139 \mathrm{THg}$ and $\mathrm{MeHg}$ concentrations were preserved with trace metal grade $\mathrm{HCl}(0.2 \%$ and $0.4 \%$ by

140 volume, respectively) and refrigerated until analysis. Methylmercury results from one of the

141 wetland ponds in the July sampling event (Pond 139) are not reported due to filter damage.

142 Porewater electrical conductivity and $\mathrm{pH}$ were measured with a YSI 556 multiprobe sonde.

143 Surface water was sampled for $\mathrm{THg}, \mathrm{MeHg}$, DOC and sulphate concentrations, $\mathrm{pH}$, and

144 electrical conductivity exactly as described for pore waters except that samples were collected by

145 wading into the centre of the wetland and sampling water from $\sim 5-10 \mathrm{~cm}$ beneath the surface.

\section{Sample Analysis}

147 Sediment MeHg and THg Concentrations and Methylation Potentials 
Freeze dried sediments collected for both enriched $\mathrm{Hg}$ isotope and ambient $\mathrm{THg}$ and $\mathrm{MeHg}$ concentrations were analyzed at the University of Alberta's Biogeochemical Analytical Service Laboratory. Budgetary constraints limited analysis to duplicate $0-2 \mathrm{~cm}$ sections from three wetland ponds selected from each of the High $\mathrm{SO}_{4}$ and $\mathrm{Low} \mathrm{SO}_{4}$ groups of wetlands. Cores with incubation lengths closest to the four-hr target incubation times were chosen for analysis. For $\mathrm{THg}$ analyses, freeze dried sediment was digested with trace metal grade $\mathrm{HNO}_{3}, \mathrm{H}_{2} \mathrm{SO}_{4}$, and $\mathrm{BrCl}$ and analyzed using a Tekran 2600 upstream of a PerkinElmer Elan DRC-e inductively coupled plasma mass spectrometer (ICP-MS). Sediment MeHg samples were distilled with small additions of $\mathrm{Me}^{199} \mathrm{Hg}$ as an internal standard (Hintelmann et al. 2000), ethylated with sodium tetraethylborate, and analyzed on a Tekran $2700 \mathrm{MeHg}$ analyzer connected to an ICPMS. Ambient $\mathrm{THg}$ and $\mathrm{MeHg}$ concentrations were calculated using the dominant ${ }^{202} \mathrm{Hg}$ isotope after correction for ${ }^{202} \mathrm{Hg}$ in the injected enriched isotope, as per Hintelmann and Evans (1997).

Methylation potentials were calculated as the amount of spike ${ }^{201} \mathrm{Hg}$ methylated to $\mathrm{Me}{ }^{201} \mathrm{Hg}$ over the incubation (Hintelmann and Evans 1997):

${ }^{201} \mathrm{Hg}$ methylation potential $\left(k_{m}\right)=-\ln \left(1-\left(\mathrm{Me}^{201} \mathrm{Hg} /{ }^{201} \mathrm{Hg}\right)\right) /($ incubation time $*(1$ day $/ 24 \mathrm{~h}))$ where: $\mathrm{Me}^{201} \mathrm{Hg}$ is the excess $\mathrm{Me}^{201} \mathrm{Hg}$ (concentration of spiked enriched stable isotope above the ambient concentration) in $\mathrm{ng} \mathrm{g}^{-1},{ }^{201} \mathrm{Hg}$ is excess ${ }^{201} \mathrm{Hg}_{\text {in }} \mathrm{ng} \mathrm{g}^{-1}$ from added spike, and incubation time is incubation length in hours. Despite our equilibration with native pore water, the newly added ${ }^{201} \mathrm{Hg}$ is likely more bioavailable than ambient inorganic $\mathrm{Hg}$, thus the resulting values represent potential methylation rate constants (Mitchell and Gilmour 2008).

Surface and Porewater MeHg, THg, DOC, and Sulphate Concentrations

Surface water and porewater $\mathrm{THg}$ concentrations were analyzed at the University of Regina by CVAFS using a Tekran 2600 following EPA Method 1631. Methylmercury concentrations were quantified using a Tekran 2700 at the University of Western Ontario, following distillation on a Tekran 2750 at the University of Regina. Sulphate and DOC were analyzed by standard methods (Stainton et al. 1977).

Quality Assurance, Quality Control

Approximately $10 \%$ of samples were analyzed in duplicate. Standard reference materials included MESS-3 (National Research Council) for THg and IAEA-405 (International Atomic 
177 Energy Agency) for $\mathrm{MeHg}$ and recoveries were generally greater than $95 \pm 2 \%$ and $99.7 \pm 0.1 \%$ for $178 \mathrm{THg}$ and $\mathrm{MeHg}$ respectively (Table S2). Average spike recoveries were between $85 \pm 4 \%$ and $179107 \pm 10 \%$ (Table S2). Minimum detection limits for water and sediment were less than $0.3 \mathrm{ng} \mathrm{L}$

$180{ }^{1}$ for $\mathrm{THg}$ and $0.02 \mathrm{ng} \mathrm{L}^{-1}$ for MeHg. Samples below the MeHg detection limit were assigned a 181 value of half the detection limit $\left(0.01 \mathrm{ng} \mathrm{L}^{-1}\right)$.

$182 \quad$ Partitioning coefficients

183 The apparent porewater / sediment partitioning coefficients $\left(\log \mathrm{K}_{\mathrm{D}}\right)$ were calculated as the 184 base-10 logarithm of the concentration in sediment $(\mathrm{ng} / \mathrm{kg})$ divided by the concentrations in 185 porewater (ng/L) (Lyon et al. 1997). Statistical Analysis

187 Data with non-normal distributions were identified using Kolmogorov-Smirnov tests and 188 natural $\log$ transformed when necessary. For negative data, values were uniformly translated to 189 positive values. Differences in potential methylation constants in ponds grouped into High $\mathrm{SO}_{4}$ 190 and Low $\mathrm{SO}_{4}$ ponds were determined by t-tests. For sediment geochemistry and mercury data, 191 two-way ANOVAs were used to test differences due to sulphate classification and time of 192 sampling (July vs. August). For all statistical tests, $\alpha=0.05$ and error bars represent standard 193 error. Associations between potential methylation rate constants and other parameters (listed in 194 Table S2) were quantified through linear regression. All interaction effects were not significant. 195 SigmaPlot $13 \circledR$ was used for statistical tests.

\section{RESULTS}

\section{Geochemical Differences Between $\mathrm{Low} \mathrm{SO}_{4}$ and High $\mathrm{SO}_{4}$ Wetland Ponds}

198 Our groups of wetland ponds had significant geochemical differences among sediment, and 199 surface and pore waters. Sediment \%OM ranged from 5.5 to $29.6 \%$ (Table S3), tended to be

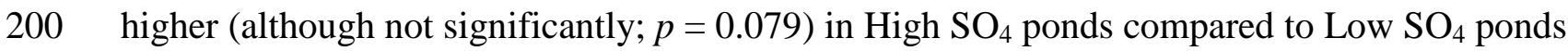
201 (Fig. S2), but did not differ between July and August ( $\mathrm{p}=0.218)$. Both surface water and 202 porewater had significantly greater sulphate concentrations (Fig. 1A/B) and related electrical 203 conductivities (Fig. 1C/D) in our High $\mathrm{SO}_{4}$ ponds. Our observed sulphate concentrations ranged 204 from 10.16 to over $3200 \mathrm{mg} \mathrm{L}^{-1}$ and 5.6 to $2600 \mathrm{mg} \mathrm{L}^{-1}$ in surface water and porewater, 205 respectively (Tables S3 and S4). pH and DOC concentrations were significantly higher in High 
206

207

208

209

210

211

212

213

214

215

216

217

218

219

220

221

222

223

224

225

226

227

228

229

230

231

232

233

234

$\mathrm{SO}_{4}$ ponds in both surface water and porewater (Fig. 1E-1H). Concentrations of DOC ranged from 9.62 to $40 \mathrm{mg} \mathrm{L}^{-1}$ and 12.73 to $88.92 \mathrm{mg} \mathrm{L}^{-1}$ for surface and porewater, respectively. Values for $\mathrm{pH}$ in all ponds were between 6.41 and 8.33 in surface water and 6.72 and 7.34 in porewater. There were no significant differences in any parameters between July and August (See Fig. 1 for $p$ values).

\section{Differences in $\mathrm{Hg}$ and MeHg Chemistry in $\mathrm{Low} \mathrm{SO}_{4}$ and High $\mathrm{SO}_{4}$ sites}

In situ sediment $k_{m}$ values in July ranged from 0.019 to $0.166 \mathrm{~d}^{-1}$ (Fig. 2A). Mean $k_{m}$ values in High $\mathrm{SO}_{4}$ ponds $\left(0.051 \pm 0.017 \mathrm{~d}^{-1}\right)$ did not differ significantly from those in Low $\mathrm{SO}_{4}$ ponds $\left(0.102 \pm 0.034 \mathrm{~d}^{-1} ; p=0.250\right.$; Fig. 2B). Concentrations of MeHg in sediment $\left(0.18-2.12 \mathrm{ng} \mathrm{g}^{-1}\right.$; Fig. 3A), surface water (below detection limit - $5.72 \mathrm{ng} \mathrm{L}^{-1}$; Fig. 3B) and porewater (0.19 to

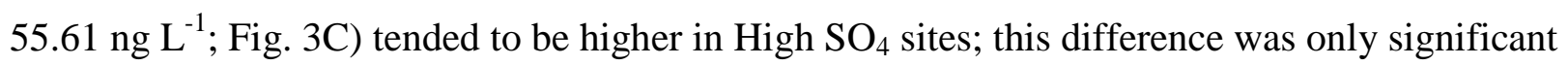
in surface water $\left(p=0.014\right.$; Table S3-S5). Total $\mathrm{Hg}$ concentrations in surface $\left(0.61-6.82 \mathrm{ng} \mathrm{L}^{-}\right.$

${ }^{1}$; Fig. 3E) and pore (3.40 to $50.6 \mathrm{ng} \mathrm{L}^{-1}$; Fig. 3F) waters also tended to be higher (again, not significantly) in $\mathrm{High} \mathrm{SO}_{4}$ sites compared to Low $\mathrm{SO}_{4}$ sites. In sediment (Fig. 3D), THg concentrations did not differ either by sulphate grouping or month ( $p=0.575$ and 0.936$)$. With the exception of sediment where there was no observed difference by month, $\mathrm{MeHg}$ and $\mathrm{THg}$ concentrations were higher in July compared to August in both surface and pore waters (see Fig. 3 for $p$ values). The proportion of $\mathrm{THg}$ that was $\mathrm{MeHg}(\% \mathrm{MeHg})$ was higher in surface (1.02$90.65 \%$; Fig. $3 \mathrm{H})$ and pore $(4.60-109.85 \%$; Fig. 3I) waters compared to sediment (0.63 4.83\%; Fig. 3G). Sediment and surface water \% MeHg were significantly greater in $\mathrm{High}_{4}$ sites compared to Low $\mathrm{SO}_{4}$ sites ( $p=0.027$ and 0.001 , respectively). Month to month differences were observed in $\% \mathrm{MeHg}$ in surface water $(p=0.036)$ and porewater $(p=0.018)$ but not sediment $(p=0.740)$. Log sediment/porewater $K_{\mathrm{D}}$ values for $\mathrm{MeHg}$ and $\mathrm{THg}$ ranged from 0.88 to $3.23 \mathrm{~L} \mathrm{~kg}^{-1}$ and 2.73 to $4.06 \mathrm{~L} \mathrm{~kg}^{-1}$, respectively (Table S6). Partitioning coefficients for both MeHg and THg were higher in August ( $p=0.016$ for $\mathrm{MeHg}$ and $p=0.005$ for $\mathrm{THg}$ ) suggesting that there was less $\mathrm{MeHg}$ and $\mathrm{THg}$ in porewater in August compared to July. Partitioning coefficients for both $\mathrm{MeHg}$ and $\mathrm{THg}$ were similar between High and $\mathrm{Low} \mathrm{SO}_{4}$ ponds $(p=0.376$ for $\mathrm{MeHg}$ and $p=0.069$ for $\mathrm{THg}$ ).

\section{Relationships among geochemical factors and $\mathrm{Hg}$ methylation potentials}


Linear regression was used to identify potential relationships among methylation potentials and factors that may impact the production of $\mathrm{MeHg}$. Porewater $\mathrm{THg}$, sulphate, and DOC concentrations, and sediment \%OM, THg concentrations and \% $\mathrm{MeHg}$, were tested as possible predictors of methylation potentials. There were no significant relationships observed between any of these variable and potential methylation rate constants (see Table S7 for $\mathrm{r}^{2}$ and $p$ values). Linear regressions also showed that neither pore water $\mathrm{THg}$ and $\mathrm{MeHg}$ concentrations nor porewater \% MeHg predicted surface water MeHg concentrations (Table S7). However, there were significant relationships between surface water $\mathrm{MeHg}$ concentrations and $\% \mathrm{MeHg}$ in sediment in July and August (Fig. 4A) and sediment $\mathrm{THg}$ and $\mathrm{MeHg}$ concentrations and \%OM in

244 July (Fig. 4 B-D).

\section{DISCUSSION}

246 A novel measurement of methylation potentials in prairie wetland sediment

247 Wetlands are the functional ecological unit of the PPR of the North American Great Plains 248 and provide vital roles in groundwater aquifer recharge, flood control and water quality, carbon 249 and nutrient sequestration, and wildlife biodiversity (Millet et al. 2009; Poiani et al. 1991).

250 Wetland ponds in this region have a wide range of $\mathrm{MeHg}$ concentrations in unfiltered surface water, with a range of reported values from 0.02 to over $9 \mathrm{ng} \mathrm{L}^{-1}$ (Bates and Hall 2012; Hall et al.

252 2009; Sando et al. 2007). Elevated water MeHg concentrations in these wetlands suggest a 253 strong potential for elevated $k_{m}$ values. Our study is the first to measure in situ $\mathrm{Hg} k_{m}$ values via 254 enriched stable isotope methods in the PPR. Despite elevated MeHg concentrations measured in 255 prairie ponds, we found that the range of $k_{\mathrm{m}}$ values from wetland sediment in the region was 256 generally similar to $k_{\mathrm{m}}$ values from other freshwater and saltwater wetlands (Table 1). Mean $k_{\mathrm{m}}$ 257 values from SDNWA wetlands $\left(0.02-0.17 \mathrm{~d}^{-1}\right)$ were most similar to values from surface 258 sediments of freshwater Arctic wetlands (0.04-0.16 d $\mathrm{d}^{-1}$; Lehnherr et al. 2012b) and were greater 259 than those in Florida Everglades (0-0.12 $\mathrm{d}^{-1}$; Gilmour et al. 1998) and in Swedish boreal (0.01$260 \quad 0.06 \mathrm{~d}^{-1}$; Tjerngren et al. 2012a) wetlands.

261 Concentrations of $\mathrm{MeHg}$ and $\mathrm{THg}$, and \% MeHg in SDNWA wetland sediments were also 262 generally similar to, or lower than, those in other freshwater ecosystems (Table 1). The most apt 263 comparison is for sediment data collected from North Dakota's Lostwood National Wildlife 264 Refuge (LNWR), located in the PPR of the northern United States. There, both $\mathrm{MeHg}(<0.4$ - 
$2654.16 \mathrm{ng} \mathrm{g}^{-1}$ ) and $\mathrm{THg}\left(6.77-99.0 \mathrm{ng} \mathrm{g}^{-1}\right)$ concentrations were similar to those in our sites (Sando 266 et al. 2007). Sediment \% MeHg values at SDNWA were similar to those from ponds at LNWR 267 (0.3 - 8.4\%; Sando et al. 2007) and other freshwater wetlands (Table 1). Freshwater wetlands 268 generally have higher \% MeHg than estuarine or marine sediments because of higher rates of net 269 methylation (Hall et al. 2008; Mitchell and Gilmour 2008).

270 Surface water $\mathrm{MeHg}$ and $\mathrm{THg}$ concentrations compared similarly to those from studies of 271 other wetlands in the PPR. Porewater MeHg and THg concentrations were within the range of 272 concentrations observed in studies in other freshwater wetlands (for example, Louisiana: Hall et 273 al. 2008), although three of our sites sampled in July had relatively higher MeHg and $\mathrm{THg}$ 274 concentrations (Fig. 3), which was reflected in partitioning coefficients from SDNWA being 275 lower than those in other freshwater systems. Thus relatively more $\mathrm{MeHg}$ and $\mathrm{THg}$ is found in 276 the more mobile porewater phase, suggesting greater ability to transfer $\mathrm{MeHg}$ produced in 277 sediment into overlying waters.

\section{Differences in $\mathrm{MeHg}$ in High $\mathrm{SO}_{4}$ ponds compared to $\mathrm{Low} \mathrm{SO}_{4}$ ponds}

279 The most striking difference between our two pond groups was the wide range of sulphate 280 observed in our ponds. Higher sulphate concentrations in both surface and pore waters in High $281 \mathrm{SO}_{4}$ wetlands suggest that these systems may experience less sulphate limitation, in turn more 282 continuously stimulating sulphate reducing bacteria, which are a significant methylating 283 organism in wetlands (Ullrich et al. 2001) and resulting in increased $k_{m}$ values. However, 284 evidence suggests that systems with high sulphate concentrations and high SRB activity result in 285 a corresponding increase in sulphide concentrations, which can have an inhibitory impact on 286 methylation (Benoit et al. 2001). Unfortunately, we did not sample our sites for sulphide 287 concentrations; however, qualitative observations of high sulphide, such as a distinct odor of $\mathrm{H}_{2} \mathrm{~S}$ 288 gas and bands of dark sediment in the cores, suggest that sulphide concentrations in our High $289 \mathrm{SO}_{4}$ wetlands were higher than in $\mathrm{Low} \mathrm{SO}_{4}$ wetlands. As a result, we expected lower potential 290 methylation rate constants in these high sulphate wetlands because sulphate concentrations were 291 well into the range in wetland systems wherein sulphide accumulation is expected to inhibit $\mathrm{Hg}$ 292 bioavailability (> 10-100 $\mathrm{mg} \mathrm{L}^{-1}$; Gilmour et al., 1998; Benoit et al. 2003). It was thus 293 surprising that we did not observe significant differences in $k_{m}$ values between $\mathrm{High} \mathrm{SO}_{4}$ and 
294 Low $\mathrm{SO}_{4}$ wetlands. Our small amount of data does suggest that rate constants were lower in 295 High $\mathrm{SO}_{4}$ wetlands (Fig. 2).

296 We also suspect that high electrical conductivities (driven by high sulphate concentrations) 297 were a major driver of low $K_{\mathrm{D}}$ 's in our systems. Partitioning coefficients for both THg and $298 \mathrm{MeHg}$ in our systems were among the lowest presented in the literature (see summary in Liu et 299 al. 2011) which indicates a preferential movement of $\mathrm{Hg}$ into porewater, compared to other 300 freshwater environments. While we lack quantitative sulphide data, the very high sulphate 301 concentrations observed in $\mathrm{High} \mathrm{SO}_{4}$ wetlands, coupled with the reducing conditions of these 302 wetlands and distinct $\mathrm{H}_{2} \mathrm{~S}$ odours, lead us to speculate that significant porewater sulphide 303 accumulation may be preferentially pulling $\mathrm{Hg}$ into the porewater phase. Sulphides are very 304 strong ligands for $\mathrm{Hg}$ species, with either dissolved sulphides themselves, polysulphides, or thiol 305 functional groups on dissolved organic matter likely responsible for the significant partitioning 306 of $\mathrm{Hg}$ into porewater observed in our study (Skyllberg 2008). As sulphide concentrations 307 increase, $\mathrm{Hg}$ solubility increases according to the formation of the species $\mathrm{HgS}_{2} \mathrm{H}^{-}$ $308>\mathrm{Hg}(\mathrm{SH})_{2}{ }^{0}>\mathrm{HgS}_{2}{ }^{2-}$ (Skyllberg, 2008) and thus the abundant sulphate (and presumably sulphide) 309 in some of our wetland systems likely led to greater $\mathrm{Hg}$ solubility than is normally observed.

$310 \quad \mathrm{High} \mathrm{SO}_{4}$ wetlands did have significantly higher $\mathrm{MeHg}$ concentrations and \% $\mathrm{MeHg}$ in both 311 sediment and surface water (Fig. 3). Two possibilities may explain this difference. First, Low $312 \mathrm{SO}_{4}$ wetlands were located at higher elevations of the study site and had lower DOC 313 concentrations and less overhanging riparian vegetation surrounding them. As a result, these 314 sites potentially experienced greater rates of photodemethylation, which in turn would result in 315 lower concentrations of $\mathrm{MeHg}$ in the water column of Low $\mathrm{SO}_{4}$ wetlands (Lehnherr et al.

316 2012a). Since our sites were shallow, usually less than $1.5 \mathrm{~m}$ deep, there is the potential for light 317 penetration to the sediment, which might also result in more photodemethylation at the sediment 318 surface. Second, and perhaps most important, the flux of $\mathrm{MeHg}$ from sediment porewater to 319 surface water may have been higher in $\mathrm{High} \mathrm{SO}_{4}$ wetlands compared to Low $\mathrm{SO}_{4}$ wetland ponds. 320 This could explain the higher surface water MeHg concentrations in those systems. In reality, it 321 is likely that a combination of these possibilities explains increased $\mathrm{MeHg}$ concentrations (and 322 corresponding \% MeHg) in water in High $\mathrm{SO}_{4}$ wetlands compared to Low $\mathrm{SO}_{4}$ wetlands.

\section{Why do $k_{m}$ values not relate to MeHg concentrations in surface water?}


In our study, methylation potentials were not correlated with porewater $\mathrm{THg}$, sulphate, and DOC concentrations or sediment \%OM, THg concentrations or \% MeHg. This was unexpected: all of these parameters have been shown to impact methylation in other sediment and wetland systems, though not all in every system. Most surprising was the absence of a relationship between measured $k_{\mathrm{m}}$ values and sediment $\mathrm{MeHg}$ concentrations, which may be due to significant variation in demethylation rates which were not measured in our study. Loss of $\mathrm{MeHg}$ via demethylation occurs within wetland sediment (Lehnherr et al. 2012a) and since net $\mathrm{Hg}$ methylation depends on the gross rates of $\mathrm{Hg}$ methylation and $\mathrm{MeHg}$ demethylation, both rates of methylation and demethylation may influence the proportion of $\mathrm{MeHg}$ in sediment (Tjerngren et al. 2012a). If rates of demethylation are relatively similar among sites, $\% \mathrm{MeHg}$ may be related to $\mathrm{Hg}$ potential methylation rates (Lehnherr et al. 2012b), however there was no significant relationship between potential rate constants and $\% \mathrm{MeHg}$ in sediment $\left(\mathrm{r}^{2}=0.164, p=\right.$ 0.426). The lack of a significant relationship between $\% \mathrm{MeHg}$ and $k_{\mathrm{m}}$ values suggests that methylation was not the main driver of sediment $\mathrm{MeHg}$ concentrations in the summer and that demethylation plays a greater role in controlling $\mathrm{MeHg}$ accumulation (Mitchell and Gilmour 2008). We suggest the measurement of potential demethylation rates (especially in systems like prairie wetlands which have significant amounts of incident radiation) accompany future studies of potential methylation rate constants.

It is also surprising that we did not see a positive relationship with sediment \%OM. In systems with higher organic matter content, we would expect two processes to impact potential methylation. First, sediments rich in OM tend to have higher oxygen penetration compared to sediment with less OM (Cai and Sayles 1996), which may inhibit the activity of anaerobic $\mathrm{Hg}$ methylating microbes. This has been observed in other systems; methylation potentials in organic sediment of Chesapeake Bay were highest in surface sediments as oxygen penetration was limited to several millimetres, while in sandy sediments of the mid-Atlantic continental shelf oxygen penetration was several centimetres and methylation potentials were higher below the oxic surface sediment (Hollweg et al. 2009). Secondly, systems with higher \%OM tend to have higher rates of microbial activity, and hence greater rates of both methylation and demethylation, depending on redox conditions (Marvin-Dipasquale et al. 2014). However, there is also the possibility of an inhibitory effect of increased OM on methylation rate constants in that organic 
matter complexation with $\mathrm{Hg}$ may decrease the bioavailability of inorganic $\mathrm{Hg}$ (Hsu-Kim et al. 2013).

Studies examining MeHg concentrations in PPR biota show that MeHg is bioaccumulating in waterfowl (Hall et al. 2009; Hall et al. 2014; Ofukany et al. 2012), fish (Hall et al. 2014), tadpoles (unpublished data-BDH), and aquatic invertebrates (Bates and Hall 2012) that use the ecosystem services available in wetlands. For example, both Hall et al. (2013) and Ofukany et al. (2012) show that MeHg in double-crested cormorants nesting on more northern, less productive lakes were lower than those nesting on prairie lakes. Predatory insects, and waterfowl preying on those organisms, have higher concentrations than those at lower trophic levels (Hall et al. 2009; Bates and Hall 2012). Regardless of the organisms studied, the fact remains that the vast majority of $\mathrm{MeHg}$ exposure to biota is as a result of in situ $\mathrm{MeHg}$ production and therefore in order to adequately understand the potential risk to organisms, we must understand net $\mathrm{MeHg}$ production. However, our work suggests that, although the measurement of potential methylation rate constants are important to the understanding of mercury cycling in wetlands, from a management perspective, measuring $\mathrm{MeHg}$ concentrations, as well as the $\% \mathrm{MeHg}$, in surface water may be sufficient to predict and assess $\mathrm{MeHg}$ risks to biota.

\section{Conclusion}

Mercury methylation potentials in July in prairie pothole wetland pond sediments were similar to those in other freshwater systems. Within prairie ponds, $\% \mathrm{MeHg}$ and $\mathrm{MeHg}$ concentrations tended to be higher in $\mathrm{High} \mathrm{SO}_{4}$ wetland sediment compared to Low $\mathrm{SO}_{4}$ wetlands. Our work suggests that measuring MeHg concentrations, rather than methylation potentials, in surface water may be a better method in predicting and assessing $\mathrm{MeHg}$ risks to biota. We also suggest the measurement of potential demethylation rates (especially in prairie wetlands which have significant amounts of incident radiation) accompany measurement of potential methylation measurements. Future research in prairie wetlands on the removal of $\mathrm{MeHg}$ through demethylation in sediments, and photodemethylation in the water column, will increase understanding of net methylation and factors leading to differences in $\mathrm{MeHg}$ concentrations in surface water, and hence biota, among wetlands. Differences in surface water $\mathrm{MeHg}$ concentrations in High $\mathrm{SO}_{4}$ wetlands compared to Low $\mathrm{SO}_{4}$ wetlands may be a consideration that stakeholders in wetland protection, reclamation, or creation consider. If it is 
385 possible to influence sulphate concentrations of wetlands during reclamation or creation and

386 subsequent management, it might be prudent to create low sulphate ponds preferentially.

\section{Acknowledgements}

388 Laboratory assistance provided by L. Bates, M. Collins, V. Bazira, S. Boczulak, and R. Rees

389 Tiller at the Universities of Regina, Alberta, and Western Ontario. Dr. B. Branfireun supported

390 analysis of MeHg in water through the Canadian Research Chair program. Dr. H. Baulch

391 supported sulphate analysis. A. Bugajski, K. Gurniak, N. Hoggarth, K. Pangracs, and D. Wright

392 were field assistants. The National Science and Engineering Research Council and the

393 University of Regina provided funding. 


\section{References:}

Alpers, C.N., Fleck, J.A., Marvin-Dipasquale, M., Stricker, C.A., Stephenson, M., Taylor, H.E., 2014. Mercury cycling in agricultural and managed wetlands, Yolo Bypass, California: Spatial and seasonal variations in water quality. Science of the Total Environment 484, 276-287.

Axelrad, D.M., Atkeson, T.D., Lange, T., Pollman, C.D., Gilmour, C.C., Orem, W.H., Mendelssohn, I.A., Frederick, P.C., Krabbenhoft, D.P., Aiken, G.R., Rumbold, D.G., Scheidt, D.J., Kalla, P.I. 2007. Chapter 3B: Mercury monitoring, Research and Environmental Assessment in South Florida. In 2007 South Florida Environmental Report: Volume I. Available at: http://my.sfwmd.gov/portal/page/portal/pg_grp_sfwmd_sfer/portlet_prevreport/ volume1/vol1_table_of_contents.html. (Accessed March 25, 2015).

Bates, L.M., Hall, B.D., 2012. Investigating the concentrations of methylmercury in invertebrates from Saskatchewan prairie pothole wetlands Environmental Pollution 160, 153-160.

Batt, B.D., Anderson, M.G., Anderson, C.D., Caswell, F.D., 1989. The use of prairie potholes by North American ducks, in: Van der Valk, A.G., editor, Northern prairie wetlands. Iowa State University Press, Ames, IA, pp. 204-227.

Benoit, J.M., Gilmour, C.C., Heyes, A., Mason, R.P., Miller, C.L., 2003. Geochemical and biological controls over methylmercury production and degradation in aquatic ecosystems. In Biogeochemistry of Environmentally Important Trace Elements. ACS Symposium Series, 835, 262-297.

Benoit, J.M., Gilmour, C.C., Mason, R.P., 2001. The influence of sulfide on solid-phase mercury bioavailability for methylation by pure cultures of Desulfobulbus propionicus (1pr3).

Environmental Science and Technology 35, 127-132.

Benoit, J.M., Gilmour, C.C., Mason, R.P., Heyes, A., 1999. Sulfide controls on mercury speciation and bioavailability to methylating bacteria in sediment pore waters. Environmental Science and Technology 33, 951-957.

Benoit, J.M., Shull, D.H., Harvey, R.M., Beal, S.A., 2009. Effect of Bioirrigation on SedimentWater Exchange of Methylmercury in Boston Harbor, Massachusetts. Environmental Science \& Technology 43, 3669-3674. 
422 Branfireun, B.A., Roulet, N.T., Kelly, C.A., Rudd, J.W.M., 1999. In situ sulphate stimulation of 423 mercury methylation in a boreal peatland: Toward a link between acid rain and methylmercury 424 contamination in remote environments. Global Biogeochemical Cycles 13, 743-750.

425 Brigham, M.E., Wentz, D.A., Aiken, G.R., Krabbenhoft, D.P., 2009. Mercury Cycling in Stream 426 Ecosystems. 1. Water Column Chemistry and Transport. Environmental Science and Technology $427 \quad 43,2720-2725$.

428 Cai, W.-J., Sayles, F., 1996. Oxygen penetration depths and fluxes in marine sediments. Marine 429 Chemistry 52, 123-131.

430 Chasar, L.C., Scudder, B.C., Stewart, R.A., Bell, A.H., Aiken, G.R., 2009. Mercury cycling in 431 stream ecosystems. 3. Trophic dynamics and methylmercury bioaccumulation. Environmental 432 Science and Technology 43, 2733-2739.

433 Coleman Wasik, J., Mitchell, C.P.J., Engstrom, D.R., Swain, E.B., Monson, B.A., Balogh, S.J., 434 Jeremiason, J.D., Branfireun, B.A., Eggert, S., Kolka, R.K., Almendinger, J.E., 2012.

435 Methylmercury declines in a boreal peatland when experimental sulfate deposition decreases.

436 Environmental Science and Technology 46, 6663-6671.

437 Environment Canada. 2002. Canadian Climate Normals 1971-2000. in.

438 Fleming, E.J., Mack, E.E., Green, P.G., Nelson, D.C., 2006. Mercury methylation from 439 unexpected sources: Molybdate-inhibited freshwater sediments and an iron-reducing bacterium. 440 Applied and Environmental Microbiology 72, 457-464.

441 Gentès, S., Monperrus, M., Legeay, A., Maury-Brachet, R., Devail, S., 2013. Incidence of 442 invasive macrophytes on methylmercury budget in temperate lakes: Central role of bacterial 443 periphytic communities. Environmental Pollution 172, 116-123.

444 Gilmour, C.C., Riedel, G.S., Ederington, M.C., Bell, J.T., Benoit, J.M., Gill, G.A., Stordal, M.C., 445 1998. Methylmercury concentrations and production rates across a trophic gradient in the 446 northern Everglades. Biogeochemistry 40, 327-345.

447 Goldhaber, M.B., Mills, C.T., Morrison, J.M., Stricker, C.A., Mushet, D.M., LaBaugh, J.W. 448 2014. Hydrogeochemistry of prairie pothole region wetlands: Role of long-term critical zone 449 processes. Chemical Geology 387, 170-183. 
Hall, B.D., Aiken, G.R., Krabbenhoft, D.P., Marvin-Dipasquale, M., Swarzenski, C.M., 2008. Wetlands as principal zones of methylmercury production in Southern Louisiana and the Gulf of Mexico region. Environmental Pollution 154, 124-134.

Hall, B.D., Baron, L.A., Somers, C.M., 2009. Mercury concentrations in surface water and

454 harvested waterfowl from the prairie pothole region of Saskatchewan. Environmental Science 455 and Technology 43, 8759-8766.

456 Hammerschmidt, C.R., Fitzgerald, W.F., 2004. Geochemical controls on the production and 457 distribution of methylmercury in near-shore marine sediments. Environmental Science and 458 Technology 38, 1487-1495.

459 Hammerschmidt, C.R., Fitzgerald, W.F., 2006. Methylmercury cycling in sediments on the 460 continental shelf of southern New England. Geochimica et Cosmochimica Acta 70, 918-930.

461 Hayashi, M., van der Kamp, G., Rudolph, D.L., 1998. Water and solute transfer between a 462 prairie wetland and adjacent uplands, 1. Water balance. Journal of Hydrology 207, 42-55.

463 Heagle, D.J., Hayashi, M., van der Kamp, G., 2007. Use of sulfur mass balance to quantify 464 geochemical processes in a prairie recharge wetland. Wetlands 27, 806-818.

465 Heiri, O., Lotter, A., Lemcke, G., 2001. Loss on ignition as a method for estimating organic and 466 carbonate content in sediments: reproducibility and comparability of results. Journal of 467 Paleolimnology 25, 101-110.

468 Hintelmann, H., 2010. Organomercurial. Their formation and pathways in the environment. Met. 469 Ions Life Sci. 7, 365-401.

470 Hintelmann, H., Evans, R.D., 1997. Application of stable isotopes in environmental tracer 471 studies - Measurement of monomethylmercury $\left(\mathrm{CH}_{3} \mathrm{Hg}^{+}\right)$by isotope dilution ICP-MS and 472 detection of species transformation. Journal of Analytical Chemistry 358, 378-385.

473 Hintelmann, H., Keppel-Jones, K., Evans, R.D., 2000. Constraints of mercury methylation and 474 demethylation rates in sediments and comparison of tracer and ambient mercury availability. 475 Environmental Toxicology and Chemistry 19, 2204-2211.

476 Hollweg, T., Gilmour, C.C., Mason, R.P., 2009. Methylmercury production in sediments of 477 Chesapeake Bay and the mid-Atlantic continental margin. Marine Chemistry 114, 86-101. 
Hsu-Kim, H., Kucharzyk, K.H., Zhang, T., Deschusses, M.A., 2013. Mechanisms regulating mercury bioavailability for methylating microorganisms in the aquatic environment: a critical review. Environmental Science \& Technology 47, 2441-2456.

Johnson, W.C., Werner, B., Guntenspergen, G.R., Voldseth, R.A., Millett, B.V., Naugle, D.E., Tulbure, M., Carroll, R.W.H., Tracy, J., Olawsky, C., 2010. Prairie wetland complexes as landschpe unctional units in a changing climate. BioScience 60, 128-140.

Kelly, C.A., Rudd, J.W.M., Holoka, M.H., 2003. Effect of pH on mercury uptake in an aquatic bacterium: Implications for Hg cycling. Environmental Science and Technology 37, 2941-2946.

Langer, C., Fitzgerald, W.F., Visscher, P., Vandal, G.M., 2001. Biogeochemical cycling of methylmercury at Barn Island Salt Marsh, Stonington, CT, USA. Wetlands Ecology and Management 9, 295-310.

Last, W.M. 1999. Geolimnology of the Great Plains of western Canada; in Holocene Climate and Environmental Change in the Palliser Triangle: A Geoscientific Context for Evaluating theImpacts of Climate Change on the Southern Canadian Prairies, (ed.) D.S. Lemmen and R.E. Vance; Geological Survey of Canada, Bulletin 534, p. 23-55.

Lehnherr, I., St Louis, V.L., Emmerton, C.A., Barker, J.D., Kirk, J.L., 2012a. Methylmercury Cycling in High Arctic Wetland Ponds: Sources and Sinks. Environmental Science \& Technology 46, 10514-10522.

Lehnherr, I., St Louis, V.L., Kirk, J.L., 2012b. Methylmercury Cycling in High Arctic Wetland Ponds: Controls on Sedimentary Production. Environmental Science \& Technology 46, 1052310531.

Liu, G., Li, Y., Cai, Y., 2011. Adsorption of Mercury on Solids in the Aquatic Environment, in: Environmental Chemistry and Toxicology of Mercury. John Wiley \& Sons, Inc., pp. 367-387. Loseto, L.L., Siciliano, S.D., Lean, D.R.S., 2004. Methylmercury production in high Arctic wetlands. Environmental Toxicology and Chemistry 23, 17-23.

Lyon, B., Ambrise, R., Rice, G., Maxwell, C., 1997. Calculation of soil-water and benthic sediment partition coefficients for mercury. Chemosphere 35, 791-808. 
505 Marvin-Dipasquale, M., Agee, J., Bouse, R.M., Jaffe, B.E., 2003. Microbial cycling of mercury 506 in contaminated pelagic and wetland sediments of San Pablo Bay, California. Environmental 507 Geology 43, 260-267.

508 Marvin-DiPasquale, M., Lutz, M.A., Brigham, M.E., Krabbenhoft, D.P., Aiken, G.R., Orem, 509 W.H., Hall, B.D., 2009. Mercury Cycling in Stream Ecosystems. 2. Benthic Methylmercury 510 Production and Bed Sediment-Pore Water Partitioning. Environmental Science \& Technology $51143,2726-2732$.

512 Marvin-Dipasquale, M., Windham-Myers, L., Agee, J.L., Kakouros, E., Kieu, L.H., Fleck, J.A., 513 Alpers, C.N., Stricker, C.A., 2014. Methylmercury production in sediment from agricultural and 514 non-agricultural wetlands in the Yolo Bypass, California, USA. Science of the Total 515 Environment 484, 288-299.

516 Mergler, D., Anderson, H.A., Chan, L.H.M., Mahaffey, K.R., Murray, M., Sakamoto, M., Stern, 517 A.H., 2007. Methylmercury exposure and health effects in humans: A worldwide concern. 518 Ambio 36, 3-11.

519 Millett, B.V., Johnson, W.C., Guntenspergen, G., 2009. Climate trends of the North America 520 prairie pothole region 1906-2000. Climatic Change 93, 243-267.

521 Mitchell, C.P.J., Branfireun, B.A., Kolka, R.K., 2007. Spatial Characteristics of Net 522 Methylmercury Production Hot Spots in Peatlands. Environmental Science and Technology 42.

523 Mitchell, C.P.J., Branfireun, B.A., Kolka, R.K., 2008. Assessing sulfate and carbon controls on 524 net methylmercury production in peatlands: An in situ mesocosm approach. Applied 525 Geochemistry 23, 503-518.

526 Mitchell, C.P.J., Gilmour, C.C., 2008. Methylmercury production in a Chesapeake Bay salt 527 marsh. Journal of Geophysical Research - Biogeosciences 113, G00C04.

528 Nachson, U., Ireson, A., van der Kamp, G., Davies, S.R., Wheater, H.S., 2014. Impacts of 529 climate variability on wetlands salinization in the North American prairies. Hydrology and Earth 530 System Sciences 18, 1251-1263.

531 Ofukany A.F.A., Hobson, K.A., Wassenaar, L.I., 2012. Connecting breeding and wintering 532 habitats of migratory piscivorous birds: implications for tracking contaminants (Hg) using 533 multiple stable isotopes. Environ Science and Technology 46:3263-3272. 
534 Pennock, D., Bedard-Haughn, A., Kiss, J., van der Kamp, G., 2014. Application of

535 hydropedology to predictive mapping of wetland soils in the Canadian Prairie Pothole Region.

536 Geoderma 235-236, 199-211.

537 Pennock, D., Yates, T., Bedard-Haughn, A., Phipps, K., Farrell, R., McDougal, R., 2010.

538 Landscape controls on $\mathrm{N} 2 \mathrm{O}$ and $\mathrm{CH} 4$ emissions from freshwater mineral soil wetlands of the 539 Canadian Prairie Pothole region. Geoderma 155, 308-319.

540 Poiani, K.A., Johnson, W.C., 1991. Global warming and prairie wetlands - potential 541 consequences for waterfowl habitat. BioScience 41, 611-618.

542 Sando, S.K., Krabbenhoft, D.P., Johnson, K.M., Lundgrean, R.F., Emerson, D.G., 2007. Mercury 543 and methylmercury in water and bottom sediments of wetlands at Lostwood National Wildlife

544 Refuge, North Dakota, 2003-2004.Survey, U.S.D.o.t.I.U.S.G. USGS Scientific Investigations

$545 \quad$ Report 2007-5219.74

546 Scheuhammer, A.M., Meyer, M.W., Sandheinrich, M.B., Murray, M.W., 2007. Effects of

547 environmental methylmercury on the health of wild birds, mammals, and fish. Ambio 36, 12-18.

548 Skyllberg, U.L., 2008. Competition among thiols and inorganic sulfides and polysulfides for $\mathrm{Hg}$

549 and $\mathrm{MeHg}$ in wetland soils and sediments under suboxic conditions: Illumination of

550 controversies and implications for MeHg net production. Journal of Geophysical Research -

551 Biogeosciences 113, G00C03.

552 St. Louis, V.L., Rudd, J.W.M., Kelly, C.A., Beaty, K.G., Bloom, N.S., Flett, R.J., 1994.

553 Importance of wetlands as sources of methyl mercury to boreal forest ecosystems. Canadian

554 Journal of Fisheries and Aquatic Sciences 51, 1065-1076.

555 Stainton, M.P., Capel, M.J., Armstrong, F.A.J., 1977. The chemical analysis of fresh

556 water.Fisheries and Marine Services Miscellaneous Special Publications. 166 pp

557 Stewart, R.E., Kantrud, H.A., 1971. Classification of natural ponds and lakes in the glaciated 558 prairie region. Resource Publication 92. United States Fish and Wildlife Services. 57

559 Tjerngren, I., Karlsson, T., Bjorn, E., Skyllberg, U., 2012a. Potential Hg methylation and MeHg 560 demethylation rates related to the nutrient status of different boreal wetlands. Biogeochemistry $561 \quad 108,335-350$. 
562 Tjerngren, I., Meili, M., Bjorn, E., Skyllberg, U., 2012b. Eight Boreal Wetlands as Sources and 563 Sinks for Methyl Mercury in Relation to Soil Acidity, C/N Ratio, and Small-Scale Flooding.

564 Environmental Science \& Technology 46, 8052-8060.

565 Ullrich, S.M., Tanton, T.W., Abdrashitova, S.A., 2001. Mercury in the aquatic environment: A 566 review of factors affecting methylation. Critical Reviews in Environmental Science and 567 Technology 31, 241-293.

568 van der Kamp, G., Hayashi, M., Gallén, D., 2003. Comparing the hydrology of grassed and 569 cultivated catchments in the semi-arid Canadian prairies. Hydrological Processes 17, 559-575.

570 Windham-Myers, L., Marvin-Dipasquale, M., Krabbenhoft, D.P., Agee, J., Cox, M., Heredia571 Middleton, P., Coates, C., Kakouros, E., 2009. Experimental removal of wetland emergent 572 vegetation leads to decreased methylmercury production in surface sediment. Journal of 573 Geophysical Research 114, G00C05.

574 Yu, R.Q., Flanders, J.R., Mack, E.E., Turner, R., Mirza, M.B., Barkay, T., 2012. Contribution of 575 Coexisting Sulfate and Iron Reducing Bacteria to Methylmercury Production in Freshwater 576 River Sediments. Environmental Science \& Technology 46, 2684-2691. 
Table 1. Methylation potential $\left(k_{\mathrm{m}} \mathrm{d}^{-1}\right)$, methylmercury $(\mathrm{MeHg})$ and total mercury $(\mathrm{THg})$ concentrations and percent of total mercury as methylmercury $(\% \mathrm{MeHg})$ for freshwater wetland, saltwater wetland, and marine surface sediment.

\begin{tabular}{lcccccl}
\hline Site & Type & $\boldsymbol{k}_{\mathbf{m}}\left(\mathbf{d}^{-1}\right)$ & $\mathbf{M e H g}\left(\mathbf{n g ~ \mathbf { ~ } ^ { - 1 } )} \mathbf{~ T H g}\left(\mathbf{n g ~ \mathbf { g } ^ { - 1 }}\right)\right.$ & $\mathbf{\%} \mathbf{M e H g}$ & Reference \\
\hline SDNWA $^{1}$ SK & Freshwater & $0.02-0.17$ & $0.18-2.1$ & $18.3-44.0$ & $0.6-4.8$ & This study \\
\hline LNWR $^{2}$ ND & Freshwater & no data & $<0.4-4.16$ & $6.77-99.0$ & $0.3-8.4$ & Sando et al. 2007 \\
\hline Arctic & Freshwater & $0.04-0.16$ & $0.6-18.5$ & $4-69$ & $1.2-12$ & Lehnherr et al. 2012b \\
\hline Florida Everglades & Freshwater & $0-0.12$ & $\sim 0.1-4.5$ & $\sim 60-410$ & $0.1-1.7$ & Gilmour et al. 1998 \\
\hline Yolo Bypass CA & Freshwater & $0.0003-1.3$ & $0.53-6.17$ & $107-433$ & $0.31-3.88$ Pers. comm. M. Marvin-Dipasquale \\
\hline Boreal Sweden & Freshwater & $0.011-0.057$ & $3.5-21$ & $113-287$ & $2.3-17$ & Tjerngren et al. 2012b \\
\hline Peatlands MN & Freshwater & $\sim 0-0.05$ & no data & no data & no data & Branfireun and Krabbenhoft, as cited in \\
& & & & & & Mitchell and Gilmour 2008 \\
\hline Connecticut & Saltwater & $\sim 0.001-0.2$ & no data & no data & no data & Langer et al. 2001 \\
\hline San Pablo Bay & Saltwater & 0.014 & $\sim 290-360$ & $\sim 0.4-5.4$ & $\sim 1.8$ & Marvin-Dipasquale et al. 2003 \\
\hline Chesapeake Bay & Saltwater & $0.002-0.07$ & $\sim 110-150$ & $\sim 1-5.5$ & $0.2-4.6$ & Mitchell and Gilmour 2008 \\
\hline San Francisco & Saltwater & $0.002-0.122$ & $0.6-3.7$ & $256-559$ & $0.1-1.4$ & Windham-Myers et al. 2009 \\
\hline Long Island Sound & Marine & $0.014-0.082$ & $0.2-3.2$ & $39-345$ & $0.4-1.1$ & Hammerschmidt and Fitzgerald 2004 \\
\hline New England shelf & Marine & $0.02-0.21$ & $0.1-3.3$ & $64-339$ & $0.4-1$ & Hammerschmidt and Fitzgerald 2006 \\
\hline Chesapeake Bay & Marine & $0.007-0.045$ & $\sim 0.2-11$ & $\sim 20-1700$ & $0.3-1.6$ & Hollweg et al. 2009 \\
\hline \hline
\end{tabular}

${ }^{1}$ SDNWA = St. Denis National Wildlife Area, Saskatchewan

${ }^{2}$ LNWR = Lostwood National Wildlife Refuge, North Dakota 
582 Figure Captions:

583 Fig. 1: Average geochemical parameters (sulphate concentrations, electrical conductivity, dissolved organic carbon [DOC] concentrations, and $\mathrm{pH})$ in surface water $(\mathrm{A}, \mathrm{C}, \mathrm{E}$, and G) and pore water (B, D, F, H) in Low $\mathrm{SO}_{4}$ (white) and High $\mathrm{SO}_{4}$ (black) wetland ponds. P-values presented refer to differences between $\mathrm{Low} \mathrm{SO}_{4}$ and $\mathrm{High} \mathrm{SO}_{4}$ wetlands (Type)

Fig. 2: Sediment mercury methylation potential rate constants $\left(\mathrm{d}^{-1}\right)$ for A: six wetlands sampled in 2011 and B: averages in Low $\mathrm{SO}_{4}$ (white) and High $\mathrm{SO}_{4}$ (black) wetland ponds. Two cores per wetland were analyzed. Error bars indicate one standard error.

Fig. 3: Average Methylmercury ( $\mathrm{MeHg}$ ) and total mercury ( $\mathrm{THg}$ ) concentrations and the proportion of total mercury that is $\mathrm{MeHg}(\% \mathrm{MeHg})$ in sediment $(\mathrm{A}, \mathrm{D}$, and $\mathrm{G})$, surface water $(\mathrm{B}, \mathrm{E}$, and $\mathrm{H})$ and porewater $(\mathrm{C}, \mathrm{F}$, and $\mathrm{I})$ in $\mathrm{Low} \mathrm{SO}_{4}$ (white) and High $\mathrm{SO}_{4}$ (black) wetland ponds. P-values presented refer to differences between Low $\mathrm{SO}_{4}$ and $\mathrm{High}_{\mathrm{SO}}$ wetlands (Type) and July and August 2011 (Month). Error bars indicate one standard error.

Fig. 4: Surface water methylmercury $(\mathrm{MeHg})$ concentrations $\left(\mathrm{ng} \mathrm{L}^{-1}\right) v s$. A: sediment $\%$ of total $\mathrm{Hg}$ that is $\mathrm{MeHg}(\% \mathrm{MeHg}), \mathrm{B}$ : sediment \% organic matter (\%OM), C: sediment $\mathrm{MeHg}$ concentrations (ng g $\left.{ }^{-1}\right)$ and D: total $\mathrm{Hg}(\mathrm{THg})$ concentrations $\left(\mathrm{ng} \mathrm{g}^{-1}\right)$. See Table S7 for $\mathrm{r}^{2}$ and $p$ values. Regression lines are only included for significant relationships. 

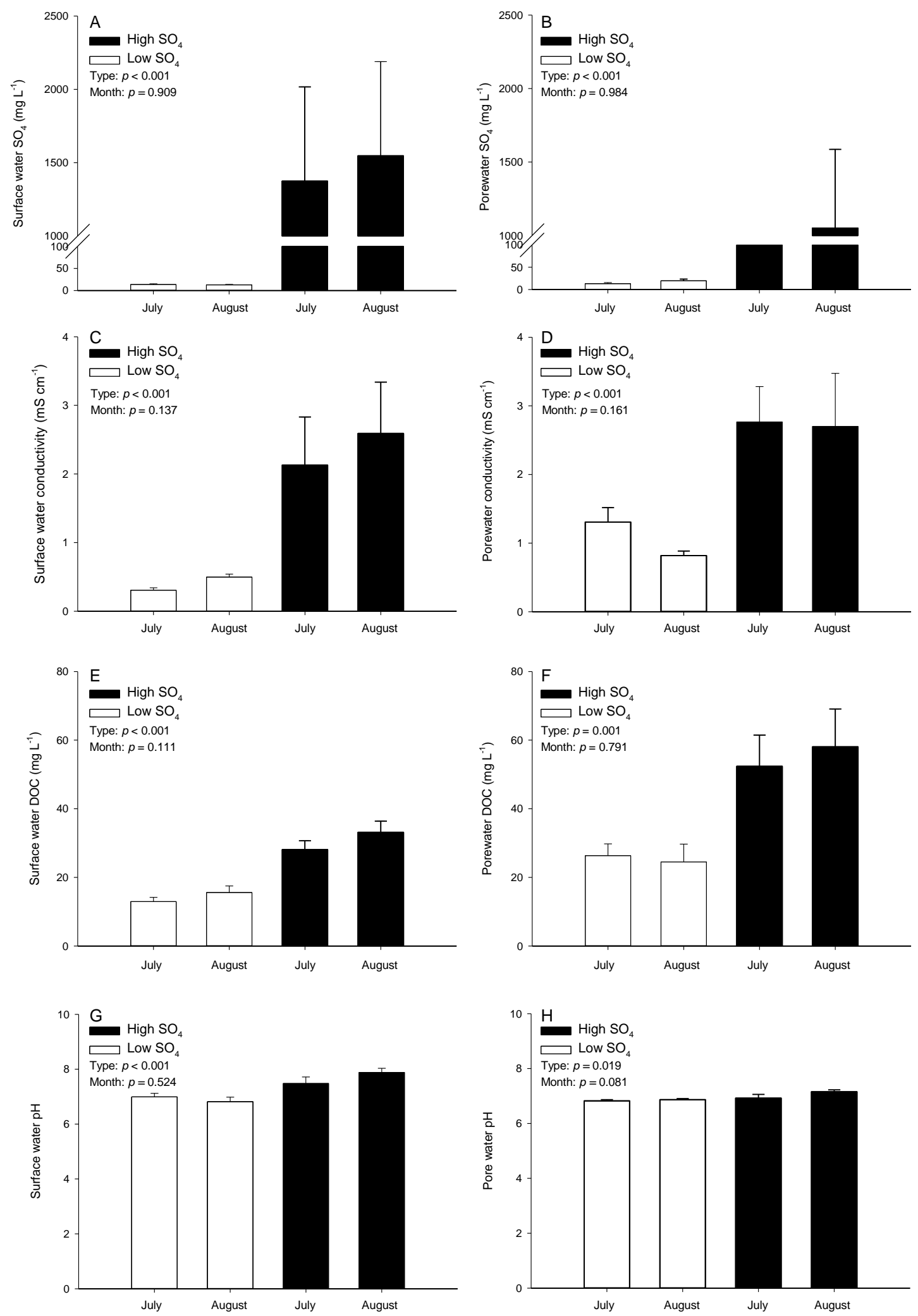

603 Fig. 1. 


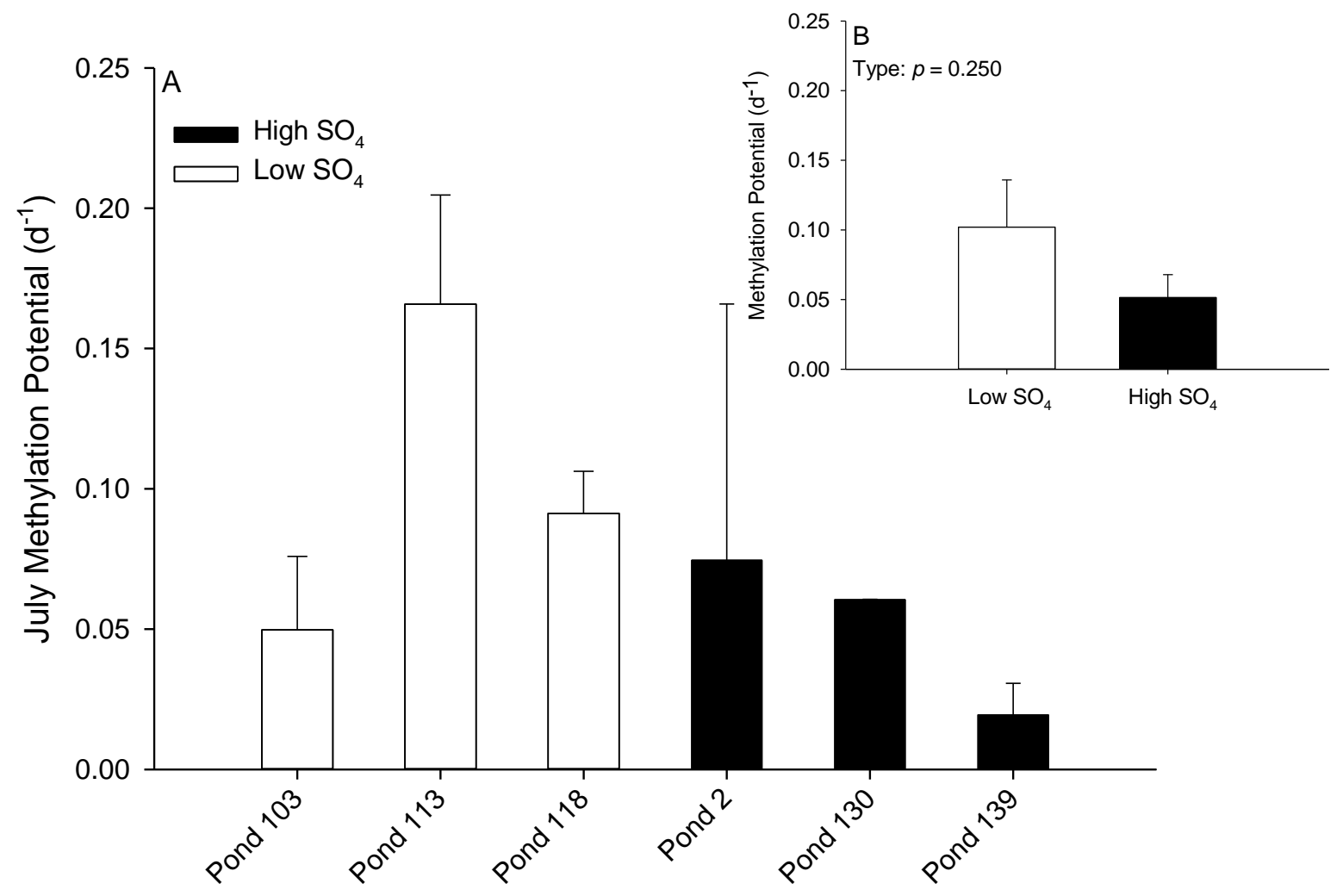

604

605

606

607

608

609

610

611

612

613

614

615

616

Fig. 2. 

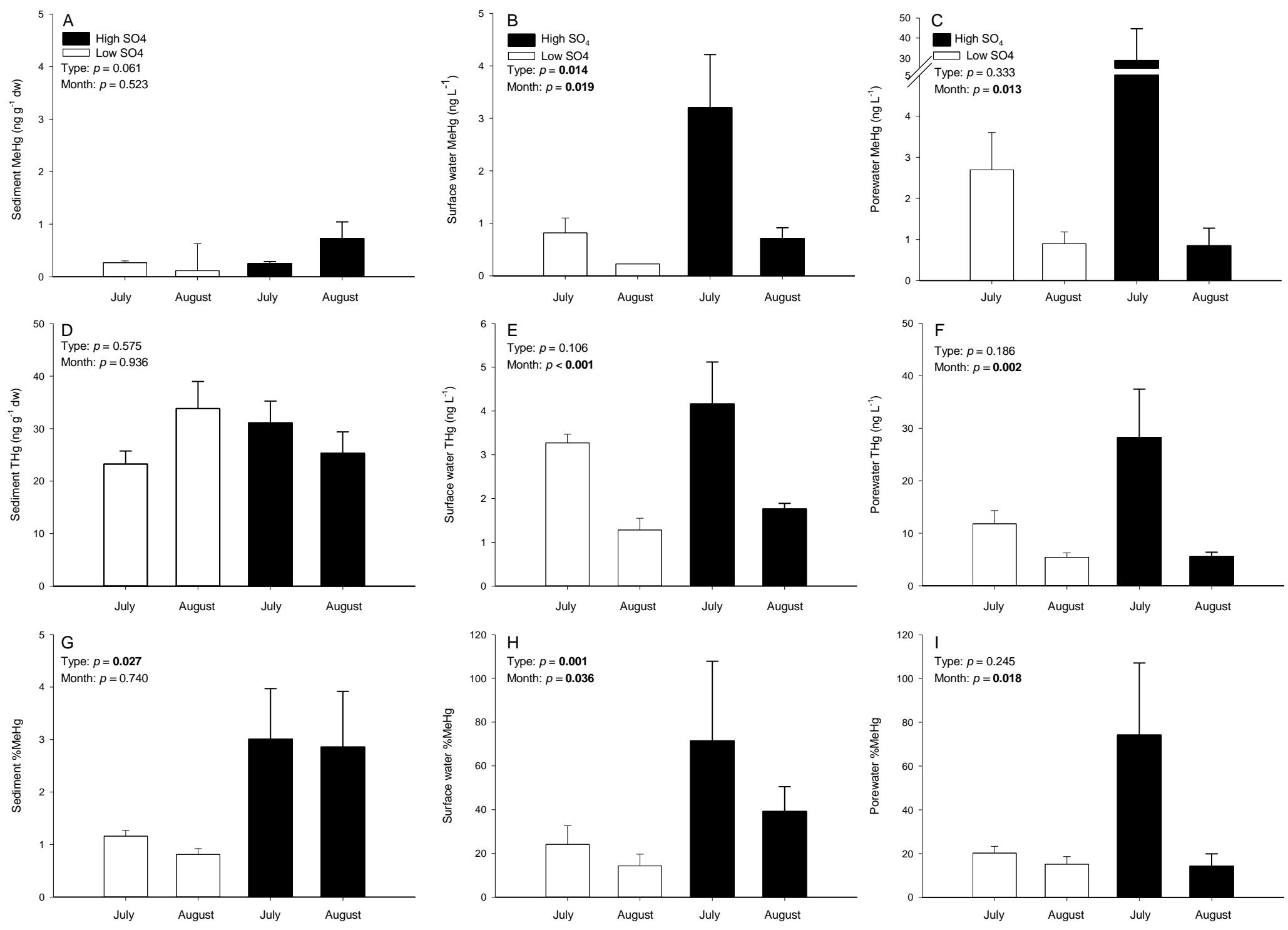

618 Figure 3 
619

620

621
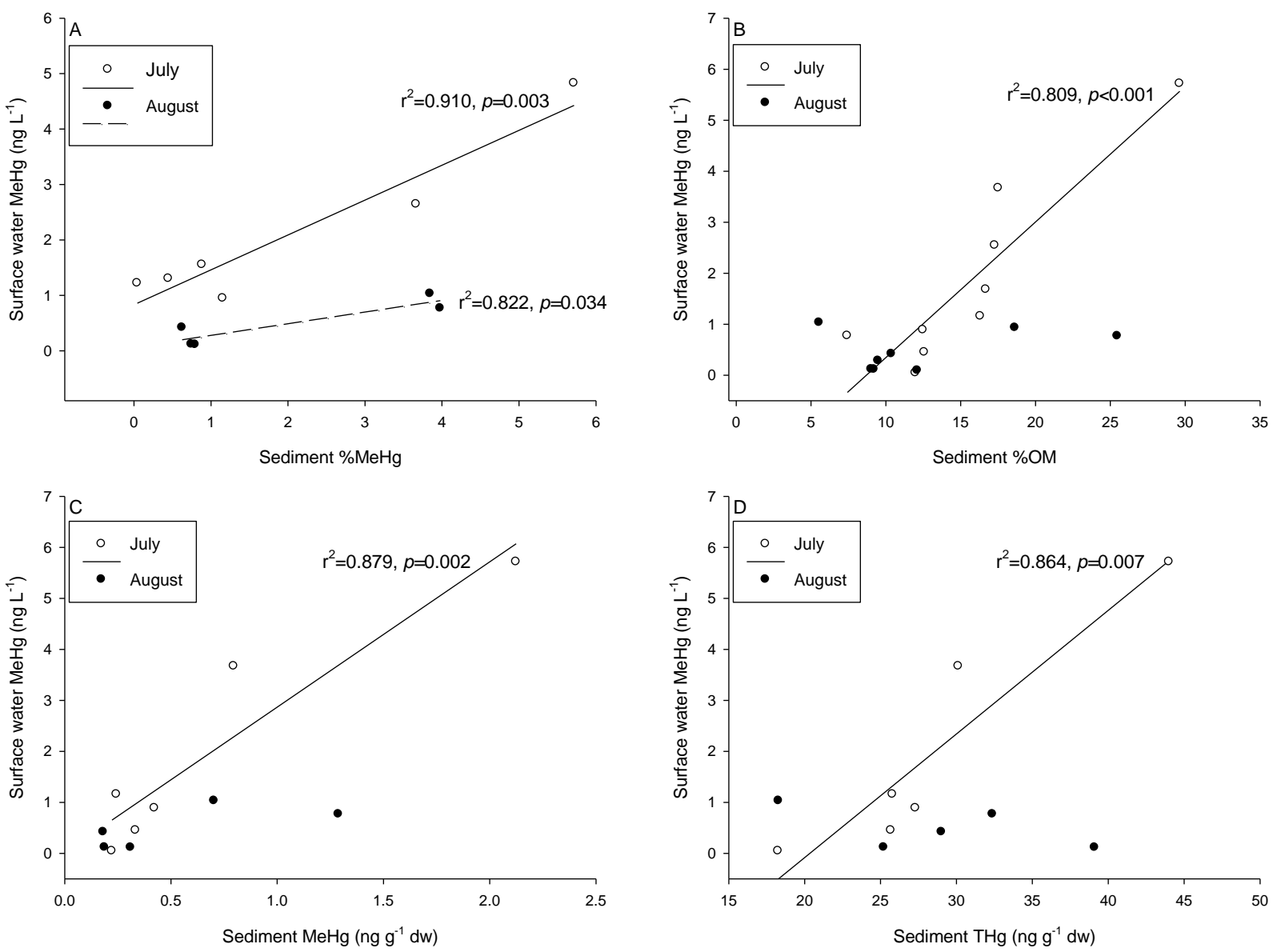

622

623

624

625

626

627

628

629

630

631

632

633

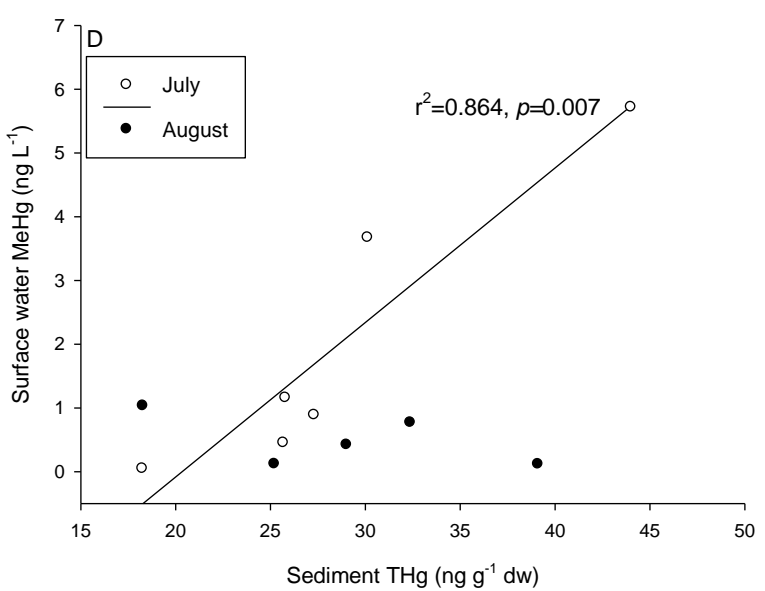

Fig. 4. 
634

635

636

637

638

639

640

641

642

643

644

645

646

647

648

649

650

651

652

653

654

655

656

657

658

659

660

661

662

Supporting Information

Mercury methylation in high and low-sulphate impacted wetland ponds within the Prairie Pothole Region of North America

Cameron G.J. Hoggarth, Britt D. Hall, and Carl P.J. Mitchell

\section{Additional Site Description}

Stewart and Kantrud's (1971) method of wetlands classification is based on vegetation characteristics but also reflects differences in water permanence. All of our wetlands were classified as Class III shallow marsh sites. Class III wetland sites are characterized seasonal ponds and lakes with a central pond that may dry up over the course of the ice-free season (typically April to October; van der Kamp et al. 2003). Representative vegetation communities are dominated by coarse grasses, sedges, and rushes that typically occur in the deepest zone.

Willow rinds surrounded most of our wetlands. Typical mean water levels in our ponds ranged from 26 to $146 \mathrm{~cm}$ (Table S1).

\section{Sediment Water and Organic Matter Content}

Sediment sections for water and organic matter content $(\% \mathrm{OM})$ were processed from a single sediment core. The entire sediment section was split into three subsamples and each subsample was measured for wet weight, dry weight after drying the samples to constant weight in an oven at $100^{\circ} \mathrm{C}$, and loss on ignition after heating the samples to $450^{\circ} \mathrm{C}$ in a muffle furnace for 8 hours. Water content was calculated as the average \%water content of the three subsamples of sediment:

$$
\% \text { water content }=\left(\left(\mathrm{WW}-\mathrm{DW}_{100}\right) / \mathrm{WW}\right) * 100
$$

where WW is the wet weight (g) of the sediment and $\mathrm{DW}_{100}$ is the dry weight $(\mathrm{g})$ of the sediment. Organic content was calculated as the average \%organic content of each of the three sediment subsamples (Chasar et al. 2009):

$$
\text { \%organic content }=\left(\left(\mathrm{DW}_{100}-\mathrm{DW}_{450}\right) / \mathrm{DW}_{100}\right) * 100
$$

where $\mathrm{DW}_{100}$ is the dry weight (g) of the sediment after heating at $100^{\circ} \mathrm{C}$, and $\mathrm{DW}_{450}$ is the dry weight $(\mathrm{g})$ after heating at $450^{\circ} \mathrm{C}$. 
663 Table S1. Latitude and longitude and water level data for wetlands sampled for sediment in 664 2011. ND= no data.

\begin{tabular}{|c|c|c|c|c|c|c|}
\hline \multirow[t]{2}{*}{ Pond } & \multirow[t]{2}{*}{ Latitude } & \multirow[t]{2}{*}{ Longitude } & \multirow[t]{2}{*}{ Wetland type } & \multicolumn{3}{|c|}{ Water level $(\mathrm{cm})$} \\
\hline & & & & May & July & October \\
\hline 100 & $52^{\circ} 12.605^{\prime}$ & $106^{\circ} 04.852^{\prime}$ & Low $\mathrm{SO}_{4}$ & 89 & 88 & 26 \\
\hline 103 & $52^{\circ} 12.567^{\prime}$ & $106^{\circ} 05.010^{\prime}$ & Low $\mathrm{SO}_{4}$ & 98 & 105 & 41 \\
\hline 110 & $52^{\circ} 12.486^{\prime}$ & $106^{\circ} 05.278^{\prime}$ & Low $\mathrm{SO}_{4}$ & 94 & 89 & 30 \\
\hline 113 & $52^{\circ} 12.634^{\prime}$ & $106^{\circ} 05.112^{\prime}$ & Low $\mathrm{SO}_{4}$ & ND & 98 & ND \\
\hline 118 & $52^{\circ} 12.587^{\prime}$ & $106^{\circ} 05.044^{\prime}$ & Low $\mathrm{SO}_{4}$ & 92 & 96 & 35 \\
\hline 2 & $52^{\circ} 12.883^{\prime}$ & $106^{\circ} 05.271^{\prime}$ & 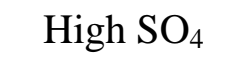 & 146.5 & 144.5 & ND \\
\hline 3 & $52^{\circ} 12.869^{\prime}$ & $106^{\circ} 05.401^{\prime}$ & $\mathrm{High} \mathrm{SO}_{4}$ & 73.5 & 68.0 & 24.0 \\
\hline 130 & $52^{\circ} 12.724^{\prime}$ & $106^{\circ} 04.688^{\prime}$ & $\mathrm{High} \mathrm{SO}_{4}$ & 111.5 & 129.0 & 105.0 \\
\hline 139 & $52^{\circ} 12.859^{\prime}$ & $106^{\circ} 05.036^{\prime}$ & $\mathrm{High} \mathrm{SO}_{4}$ & ND & ND & 56.0 \\
\hline
\end{tabular}


670 Table S2. Quality assurance and quality control for total mercury (THg) and 671 methylmercury $(\mathrm{MeHg})$ analysis of water and sediment samples with recovery of 672 standard reference materials (SRM) or spiked samples \pm one standard deviation. 673 Approximately $10 \%$ of samples for all parameters were analyzed in duplicate. Water 674 Minimum detection limits for water and sediment were less than $0.3 \mathrm{ng} \mathrm{L}^{-1}$ for $\mathrm{THg}$ 675 and $0.02 \mathrm{ng} \mathrm{L}^{-1}$ for $\mathrm{MeHg}$. $\mathrm{NA}=$ none available.

676

\begin{tabular}{cccc}
\hline Matrix and Analyte & SRM & \% Recovery & $\begin{array}{c}\text { Spike } \\
\text { \% Recovery }\end{array}$ \\
\hline Sediment THg & MESS-3 & $95 \pm 2 \%$ & $85 \pm 4 \%$ \\
\hline Sediment MeHg & IAEA-405 & $99.7 \pm 0.1 \%$ & $105 \pm 15 \%$ \\
\hline Surface and porewater THg & MESS-3 & $95 \pm 2 \%$ & $92 \pm 13 \%$ \\
\hline Surface and porewater MeHg & NA & NA & $107 \pm 10 \%$ \\
\hline \hline
\end{tabular}


679 Table S3. Sediment \% organic matter, methylmercury $(\mathrm{MeHg}$ ) and total $\mathrm{Hg}(\mathrm{THg})$ 680 concentrations, and the proportion of $\mathrm{THg}$ that is $\mathrm{MeHg}(\% \mathrm{MeHg})$ in sediment for wetlands 681 sampled in 2011. ND indicates sites with no data. For OM, n=1. For MeHg and THg, n=2.

\begin{tabular}{lcccccccc}
\hline Pond & $\begin{array}{c}\text { Organic Matter } \\
(\%)\end{array}$ & \multicolumn{2}{c}{$\begin{array}{c}\text { MeHg } \\
\left(\mathbf{n g ~ g}^{-1}\right)\end{array}$} & \multicolumn{2}{c}{$\begin{array}{c}\text { THg } \\
\left(\mathbf{n g ~ g}^{-1}\right)\end{array}$} & \multicolumn{2}{c}{$\%$ MeHg } \\
& July & Aug & July & Aug & July & Aug & July & Aug \\
\hline Low $\mathrm{SO}_{4}$ wetland ponds & & & & & & & \\
\hline 100 & 7.4 & 12.1 & ND & ND & ND & ND & ND & ND \\
103 & 12.6 & 11.2 & 0.334 & 0.254 & 25.69 & 25.15 & 1.30 & 1.01 \\
110 & 16.7 & 9.5 & ND & ND & ND & ND & ND & ND \\
113 & 12.0 & 9.2 & 0.223 & 0.311 & 18.26 & 39.12 & 1.22 & 0.76 \\
118 & 16.3 & 10.4 & 0.244 & 0.182 & 25.80 & 29.02 & 0.95 & 0.63 \\
\hline Low $\mathrm{SO}_{4}$ & 13.00 & 10.48 & 0.267 & 0.115 & 23.25 & 33.82 & 1.16 & 0.81 \\
mean & \pm 1.69 & \pm 0.54 & \pm 0.034 & \pm 0.516 & \pm 2.49 & \pm 5.16 & \pm 0.11 & \pm 0.11 \\
\hline High $\mathrm{SO}_{4}$ wetland ponds & & & & & & & \\
\hline 2 & 12.5 & 9.0 & 0.424 & 0.188 & 27.31 & 25.22 & 1.55 & 0.75 \\
3 & 17.3 & 18.6 & ND & ND & ND & ND & ND & ND \\
130 & 29.6 & 25.5 & 2.124 & 1.289 & 44.02 & 32.39 & 4.83 & 3.98 \\
139 & 17.5 & 5.5 & 0.796 & 0.703 & 30.13 & 18.28 & 2.64 & 3.85 \\
\hline High $\mathrm{SO}_{4}$ & 19.23 & 14.67 & 0.249 & 0.727 & 31.10 & 25.30 & 3.01 & 2.86 \\
mean & \pm 3.66 & \pm 4.54 & \pm 0.037 & \pm 0.318 & \pm 4.16 & \pm 4.07 & \pm 0.96 & \pm 1.06 \\
\hline \hline
\end{tabular}


Hoggarth et al. Potential rates of Hg methylation in prairie sediments Page 32 of 37

683

684

685

686

Table S4. Surface water electrical conductivity and pH, and dissolved organic carbon (DOC), sulphate, methylmercury (MeHg) and total mercury $(\mathrm{THg})$ concentrations for wetlands sampled in 2011. For all parameters $\mathrm{n}=1$.

\begin{tabular}{|c|c|c|c|c|c|c|c|c|c|c|c|c|c|c|}
\hline \multirow[t]{2}{*}{ Pond } & \multicolumn{2}{|c|}{$\begin{array}{l}\text { Surface water } \\
\text { conductivity } \\
\left(\mathrm{mS} \mathrm{cm} \mathbf{c m}^{-1}\right)\end{array}$} & \multicolumn{2}{|c|}{$\begin{array}{c}\text { Surface water } \\
\text { pH }\end{array}$} & \multicolumn{2}{|c|}{$\begin{array}{c}\text { Surface water } \\
\text { DOC } \\
\left(\mathrm{mg} \mathrm{L}^{-1}\right)\end{array}$} & \multicolumn{2}{|c|}{$\begin{array}{c}\text { Surface water } \\
\text { sulphate }\left(\mathrm{mg} \mathrm{L}^{-1}\right)\end{array}$} & \multicolumn{2}{|c|}{$\begin{array}{l}\text { Surface water } \\
\operatorname{MeHg}\left(\operatorname{ng~L}^{-1}\right)\end{array}$} & \multicolumn{2}{|c|}{$\begin{array}{l}\text { Surface water } \\
\text { THg }\left(\operatorname{ng~L}^{-1}\right)\end{array}$} & \multicolumn{2}{|c|}{$\begin{array}{c}\text { Surface water } \\
\% \mathrm{MeHg}\end{array}$} \\
\hline & July & Aug & July & Aug & July & Aug & July & Aug & July & Aug & July & Aug & July & Aug \\
\hline \multicolumn{15}{|c|}{ Low $\mathrm{SO}_{4} \mathrm{~S}$} \\
\hline 100 & 0.44 & 0.60 & 7.27 & 7.35 & 15.35 & 18.57 & 11.13 & 12.35 & 0.772 & 0.092 & 3.66 & 1.30 & 21.10 & 7.07 \\
\hline 103 & 0.23 & 0.34 & 6.98 & 6.95 & 12.77 & 12.73 & 11.50 & 10.57 & 0.448 & ND & 3.58 & 0.99 & 12.52 & 1.02 \\
\hline 110 & 0.30 & 0.51 & 6.58 & 6.53 & 16.01 & 21.73 & 12.11 & 16.10 & 1.678 & 0.282 & 3.37 & 2.24 & 49.79 & 12.60 \\
\hline 113 & 0.27 & 0.57 & 7.26 & 6.41 & 9.62 & 12.24 & 12.60 & 10.25 & 0.043 & 0.111 & 2.52 & 0.61 & 1.72 & 18.23 \\
\hline 118 & 0.29 & 0.47 & 6.86 & 6.82 & 10.96 & 12.59 & 19.70 & 13.82 & 1.155 & 0.417 & 3.25 & 1.29 & 35.60 & 32.47 \\
\hline \multicolumn{15}{|l|}{ Low } \\
\hline $\begin{array}{l}\mathrm{SO}_{4} \\
\text { mean }\end{array}$ & $\begin{array}{c}0.31 \\
\pm 0.03\end{array}$ & $\begin{array}{c}0.50 \\
\pm 0.05\end{array}$ & $\begin{array}{c}6.99 \\
\pm 0.13\end{array}$ & $\begin{array}{c}6.81 \\
\pm 0.17\end{array}$ & $\begin{array}{l}12.94 \\
\pm 1.23\end{array}$ & $\begin{array}{l}15.57 \\
\pm 1.94\end{array}$ & $\begin{array}{c}13.41 \pm \\
1.59\end{array}$ & $\begin{array}{l}12.62 \pm \\
2.42\end{array}$ & $\begin{array}{c}0.819 \\
\pm 0.282\end{array}$ & $\begin{array}{c}0.226 \\
\pm 0.069\end{array}$ & $\begin{array}{c}3.27 \\
\pm 0.20\end{array}$ & $\begin{array}{l}1.28 \\
\pm 0.27\end{array}$ & $\begin{array}{l}24.15 \\
\pm 8.47\end{array}$ & $\begin{array}{r}14.28 \\
\pm 5.37\end{array}$ \\
\hline \multicolumn{15}{|c|}{$\mathrm{High} \mathrm{SO}_{4}$} \\
\hline 2 & 3.89 & 4.40 & 8.16 & 8.33 & 28.64 & 26.42 & 3119.13 & 3246.31 & 0.886 & 0.116 & 2.27 & 1.46 & 39.11 & 7.95 \\
\hline 3 & 2.58 & 3.15 & 7.24 & 7.73 & 29.81 & 28.74 & 1498.58 & 1970.47 & 2.544 & 0.930 & 3.53 & 1.64 & 72.07 & 56.90 \\
\hline 130 & 0.75 & 1.01 & 7.41 & 7.67 & 20.75 & 37.32 & 164.57 & 197.62 & 5.715 & 0.766 & 6.82 & 2.08 & 83.87 & 36.93 \\
\hline 139 & 1.30 & 1.81 & 7.1 & 7.79 & 33.09 & 39.99 & 714.39 & 770.24 & 3.667 & 1.030 & 4.05 & 1.8885 & 90.65 & 54.91 \\
\hline \multicolumn{15}{|l|}{ High } \\
\hline $\begin{array}{l}\mathrm{SO}_{4} \\
\text { mean }\end{array}$ & $\begin{array}{c}2.13 \\
\pm 0.07\end{array}$ & $\begin{array}{c}2.59 \\
\pm 0.75\end{array}$ & $\begin{array}{c}7.48 \\
\pm 0.24\end{array}$ & $\begin{array}{c}7.88 \\
\pm 0.15\end{array}$ & $\begin{array}{l}28.07 \\
\pm 2.62\end{array}$ & $\begin{array}{l}33.12 \\
\pm 3.28\end{array}$ & $1374.17 \pm 642.83$ & $\begin{array}{l}1546.16 \\
\pm 676.46\end{array}$ & $\begin{array}{l}3.203 \\
\pm 1.01\end{array}$ & $\begin{array}{c}0.711 \\
\pm 0.205\end{array}$ & $\begin{array}{c}4.16 \pm \\
0.96\end{array}$ & $\begin{array}{c}1.76 \pm \\
0.13\end{array}$ & $\begin{array}{r}71.43 \\
\pm 36.39\end{array}$ & $\begin{array}{r}39.17 \\
\pm 11.34\end{array}$ \\
\hline
\end{tabular}


Hoggarth et al. Potential rates of Hg methylation in prairie sediments Page 33 of 37

688

689

690
Table S5. Porewater electrical conductivity and $\mathrm{pH}$, and dissolved organic carbon (DOC), sulphate, methylmercury (MeHg) and total mercury (THg) concentrations for wetlands sampled in 2011. For all parameters $n=1$.

\begin{tabular}{|c|c|c|c|c|c|c|c|c|c|c|c|c|c|c|}
\hline \multirow[t]{2}{*}{ Pond } & \multicolumn{2}{|c|}{$\begin{array}{l}\text { Porewater } \\
\text { conductivity } \\
\left(\mathbf{m S ~ c m}^{-1}\right)\end{array}$} & \multicolumn{2}{|c|}{$\begin{array}{c}\text { Porewater } \\
\text { pH }\end{array}$} & \multicolumn{2}{|c|}{$\begin{array}{c}\text { Porewater } \\
\text { DOC } \\
\left(\mathrm{mg} \mathrm{L}^{-1}\right)\end{array}$} & \multicolumn{2}{|c|}{$\begin{array}{c}\text { Porewater } \\
\text { sulphate }\left(\mathrm{mg} \mathrm{L}^{-1}\right)\end{array}$} & \multicolumn{2}{|c|}{$\begin{array}{c}\text { Porewater } \\
\operatorname{MeHg}\left(n g L^{-1}\right)\end{array}$} & \multicolumn{2}{|c|}{$\begin{array}{c}\text { Porewater } \\
\text { THg }(\text { ng L L } \\
\text {-1 })\end{array}$} & \multicolumn{2}{|c|}{$\begin{array}{c}\text { Porewater } \\
\% \mathrm{MeHg}\end{array}$} \\
\hline & July & Aug & July & Aug & July & Aug & July & Aug & July & Aug & July & Aug & July & Aug \\
\hline $\begin{array}{l}\text { Low } \mathrm{SO}_{4} \\
100\end{array}$ & 1.04 & 0.72 & 6.97 & 6.89 & 2.87 & 32.08 & 9.93 & 14.11 & 1.980 & 0.388 & 10.25 & 4.66 & 19.28 & 8.34 \\
\hline 103 & 1.47 & 0.95 & 6.77 & 6.84 & 37.40 & 12.73 & 19.26 & 18.98 & 5.927 & 1.006 & 19.52 & 6.00 & 30.36 & 16.76 \\
\hline 110 & 0.99 & 0.65 & 6.72 & 6.99 & 31.13 & 40.59 & 15.34 & 33.42 & 3.061 & 1.809 & 14.15 & 8.38 & 21.63 & 21.60 \\
\hline 113 & 0.97 & 1.00 & 6.83 & 6.76 & 19.62 & 16.48 & 5.62 & 20.04 & 0.457 & 0.192 & 4.12 & 3.40 & 11.09 & 5.64 \\
\hline 118 & 2.07 & 0.76 & 6.83 & 6.85 & 20.70 & 20.75 & 15.44 & 10 & 2.055 & 1.083 & 1094 & 4.69 & 18.79 & 23.12 \\
\hline Low & & & & & & & & & & & & & & \\
\hline $\begin{array}{l}\mathrm{SO}_{4} \\
\text { mean }\end{array}$ & $\begin{array}{c}1.31 \\
\pm 0.21\end{array}$ & $\begin{array}{c}0.82 \\
\pm 0.07\end{array}$ & $\begin{array}{c}6.82 \\
\pm 0.04 \\
\end{array}$ & $\begin{array}{c}6.87 \\
\pm 0.04 \\
\end{array}$ & $.34 \pm 3.42$ & $\begin{array}{l}24.53 \\
\pm 5.16 \\
\end{array}$ & $\begin{array}{l}13.12 \\
\pm 2.39 \\
\end{array}$ & $\begin{array}{r}19.47 \\
\pm 3.86 \\
\end{array}$ & $\begin{array}{c}2.695 \\
\pm 0.909\end{array}$ & $\begin{array}{c}0.896 \\
\pm 0.286 \\
\end{array}$ & $\begin{array}{l}11.80 \\
\pm 2.52\end{array}$ & $\begin{array}{c}5.42 \\
\pm 0.85\end{array}$ & $\begin{array}{l}20.23 \\
\pm 3.09\end{array}$ & $\begin{array}{r}15.09 \\
\pm 3.50\end{array}$ \\
\hline High S & & & & & & & & & & & & & & \\
\hline 2 & 4.17 & 3.33 & 7.05 & 7.01 & 70.55 & 56.72 & 148.50 & 2600.76 & 55.605 & 0.309 & 50.62 & 6.13 & 109.85 & 5.04 \\
\hline 3 & 2.89 & 4.55 & 7.24 & 7.17 & 42.45 & 88.92 & 1573.30 & 801 & 0.458 & 0.220 & 5.45 & 4.79 & 8.39 & 4.60 \\
\hline 130 & 1.92 & 1.06 & 6.73 & 7.34 & 44.07 & 37.32 & 123.35 & 142.14 & 30.161 & 0.767 & 28.94 & 3.90 & 104.22 & 19.67 \\
\hline 139 & 2.08 & 1.87 & 6.67 & 7.11 & ND & 49.26 & 300.59 & 655.98 & 49.268 & 2.088 & 27.96 & 7.56 & 176.21 & 27.60 \\
\hline High & & & & & & & & & & & & & & \\
\hline $\begin{array}{l}\mathrm{SO}_{4} \\
\text { mean }\end{array}$ & $\begin{array}{c}2.77 \pm \\
0.52\end{array}$ & $\begin{array}{c}2.70 \pm \\
0.77\end{array}$ & $\begin{array}{c}6.92 \\
\pm 0.14\end{array}$ & $\begin{array}{c}7.16 \\
\pm 0.07\end{array}$ & $52.36 \pm 9.11$ & $\begin{array}{c}58.05 \\
\pm 11.04\end{array}$ & $\begin{array}{r}536.43 \\
\pm 347.83 \\
\end{array}$ & $\begin{array}{c}1050 \\
\pm 535.88 \\
\end{array}$ & $\begin{array}{c}33.873 \\
\pm 12.381 \\
\end{array}$ & $\begin{array}{c}0.846 \\
\pm 0.431\end{array}$ & $\begin{array}{l}28.24 \\
\pm 9.22\end{array}$ & $\begin{array}{c}5.60 \\
\pm 0.80\end{array}$ & $\begin{array}{r}99.37 \\
\pm 34.54 \\
\end{array}$ & $\begin{array}{r}14.23 \\
\pm 5.67\end{array}$ \\
\hline
\end{tabular}


691 Table S6. Log sediment/porewater total mercury $\left(\mathrm{THg} \mathrm{K}_{\mathrm{D}}\right)$ and methylmercury $(\mathrm{MeHg}$ $692 \mathrm{~K}_{\mathrm{D}}$ ) partitioning coefficients $\left(\mathrm{L} \mathrm{kg}^{-1}\right)$ for wetlands sampled in 2011. ND indicates sites 693 with no data. For all parameters $n=1$.

694

\begin{tabular}{|c|c|c|c|c|}
\hline \multirow[t]{2}{*}{ Pond } & \multicolumn{2}{|c|}{$\begin{array}{l}\text { THg K } \\
\left(\mathrm{L} \mathrm{kg}^{-1}\right)\end{array}$} & \multicolumn{2}{|c|}{$\begin{array}{c}\underset{\left(\mathrm{L} \mathrm{kg}^{-1}\right)}{\operatorname{MeHg} \mathbf{K}_{\mathrm{D}}} \\
\end{array}$} \\
\hline & July & August & July & August \\
\hline \multicolumn{5}{|l|}{ Low $\mathrm{SO}_{4}$} \\
\hline 100 & ND & ND & ND & ND \\
\hline 103 & 3.12 & 3.62 & 1.751 & 2.403 \\
\hline 110 & ND & ND & ND & ND \\
\hline 113 & 3.65 & 4.06 & 2.688 & 3.210 \\
\hline 118 & 3.37 & 3.79 & 2.075 & 2.225 \\
\hline Low $\mathrm{SO}_{4}$ & 3.38 & 3.83 & 2.117 & 2.613 \\
\hline mean & \pm 0.15 & \pm 0.13 & \pm 0.275 & \pm 0.303 \\
\hline \multicolumn{5}{|l|}{$\mathrm{High} \mathrm{SO}_{4}$} \\
\hline 2 & 2.73 & 3.61 & 0.882 & 2.784 \\
\hline 3 & ND & ND & ND & ND \\
\hline 130 & 3.18 & 3.92 & 1.848 & 3.225 \\
\hline 139 & 3.03 & 3.38 & ND & 2.539 \\
\hline $\mathrm{High} \mathrm{SO}_{4}$ & 2.982 & 3.64 & 1.365 & 2.846 \\
\hline mean & \pm 0.13 & \pm 0.16 & \pm 0.483 & \pm 0.204 \\
\hline
\end{tabular}

695 
696

697

698

699

700

701

702

Table S7. Selected regression parameters related to methylmercury (MeHg) production and geochemical parameters. Bold type indicates significance at $\alpha$ $=0.05$. $\mathrm{ND}=$ no data. $k_{m}=$ methylation potentials, $\mathrm{THg}=$ total $\mathrm{Hg}, \mathrm{DOC}=$ dissolved organic carbon, $\% \mathrm{OM}=\%$ organic matter, $\% \mathrm{MeHg}=$ proportion of $\mathrm{THg}$ that is $\mathrm{MeHg}$.

\begin{tabular}{llcccc}
\hline $\begin{array}{c}\text { Independent } \\
\text { variable }\end{array}$ & $\begin{array}{c}\text { Dependent } \\
\text { variable }\end{array}$ & $\begin{array}{c}\mathbf{r}^{2} \\
\text { July }\end{array}$ & $\begin{array}{c}\boldsymbol{p} \text { - } \\
\text { value } \\
\text { July }\end{array}$ & $\begin{array}{c}\mathbf{r}^{2} \\
\text { August }\end{array}$ & $\begin{array}{c}\boldsymbol{p} \text {-value } \\
\text { August }\end{array}$ \\
\hline$k_{m}$ & Porewater $\mathrm{THg}$ & 0.292 & 0.268 & $\mathrm{ND}$ & $\mathrm{ND}$ \\
\hline$k_{m}$ & Porewater $\mathrm{sulphate}$ & 0.460 & 0.139 & $\mathrm{ND}$ & $\mathrm{ND}$ \\
\hline$k_{m}$ & Porewater $\mathrm{DOC}$ & 0.289 & 0.350 & $\mathrm{ND}$ & $\mathrm{ND}$ \\
\hline$k_{m}$ & Sediment $\mathrm{THg}$ & 0.329 & 0.234 & $\mathrm{ND}$ & $\mathrm{ND}$ \\
\hline$k_{m}$ & Sediment \%OM & 0.114 & 0.512 & $\mathrm{ND}$ & $\mathrm{ND}$ \\
\hline & & & & & \\
\hline Porewater $\mathrm{MeHg}$ & Surface $\mathrm{MeHg}$ & 0.075 & 0.512 & 0.154 & 0.336 \\
\hline Porewater $\mathrm{THg}$ & Surface $\mathrm{MeHg}$ & 0.070 & 0.493 & 0.022 & 0.726 \\
\hline $\begin{array}{l}\text { Porewater } \\
\% \mathrm{MeHg}\end{array}$ & Surface $\mathrm{MeHg}$ & 0.253 & 0.204 & 0.192 & 0.271 \\
\hline
\end{tabular}

\begin{tabular}{llcccc}
\hline Sediment \%OM & Surface $\mathrm{MeHg}$ & 0.809 & $<\mathbf{0 . 0 0 1}$ & 0.119 & 0.403 \\
\hline Sediment $\mathrm{MeHg}$ & Surface $\mathrm{MeHg}$ & 0.879 & $\mathbf{0 . 0 0 6}$ & 0.497 & 0.184 \\
\hline Sediment $\mathrm{THg}$ & Surface $\mathrm{MeHg}$ & 0.864 & $\mathbf{0 . 0 0 7}$ & 0.332 & 0.309 \\
\hline Sediment $\% \mathrm{MeHg}$ & Surface $\mathrm{MeHg}$ & 0.910 & $\mathbf{0 . 0 0 3}$ & 0.822 & $\mathbf{0 . 0 3 4}$ \\
\hline Sediment \%MeHg & $k_{m}$ & 0.164 & 0.426 & ND & ND \\
\hline \hline
\end{tabular}


705 See ppt file

706

707

708

709 Fig. S1. Location of sampling sites in St. Denis National Wildlife area (SDNWA),

710 Saskatchewan, Canada. 


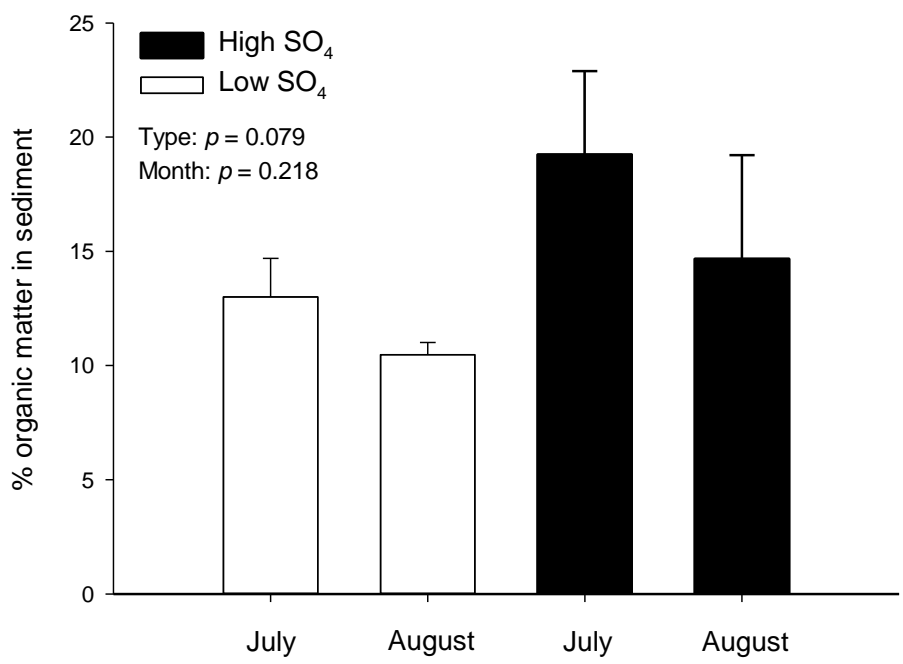

713 Fig. S2. Organic matter content (\%) and porosity in sediment from $\mathrm{Low} \mathrm{SO}_{4}$ and $\mathrm{High} \mathrm{SO}_{4}$ wetland ponds. P-values presented refer to differences between Low $\mathrm{SO}_{4}$ and $\mathrm{High}_{\mathrm{SO}} \mathrm{S}_{4}$ wetland ponds (Type) and July and August 2011 (Month). Error bars represent one standard error.

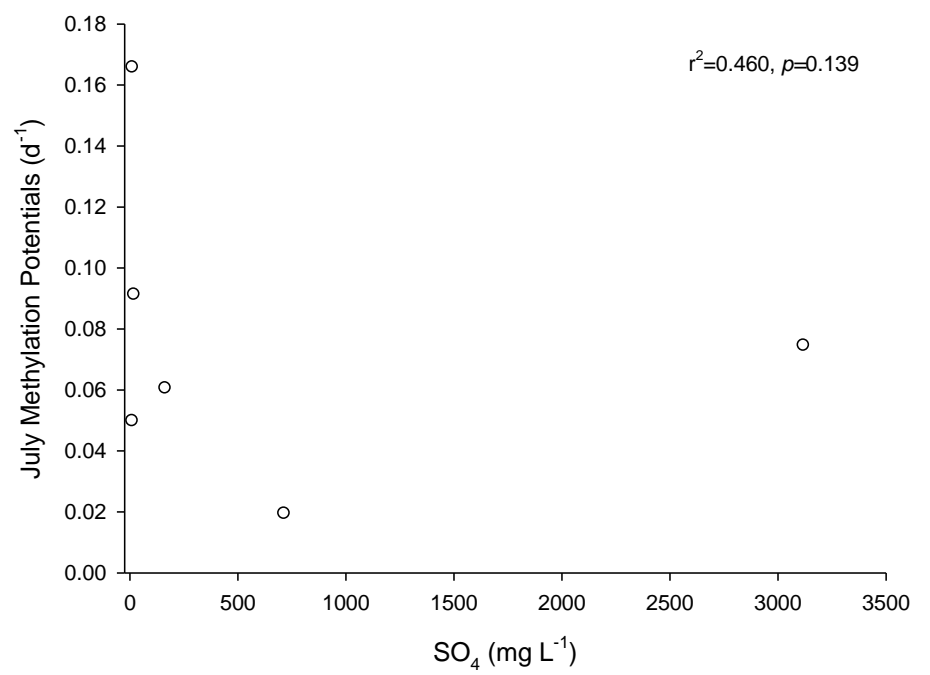




\section{Fure}

Click here to download Figure: Figure S1 HOGGARTH et al.ppt

1. Saskatoon, SK

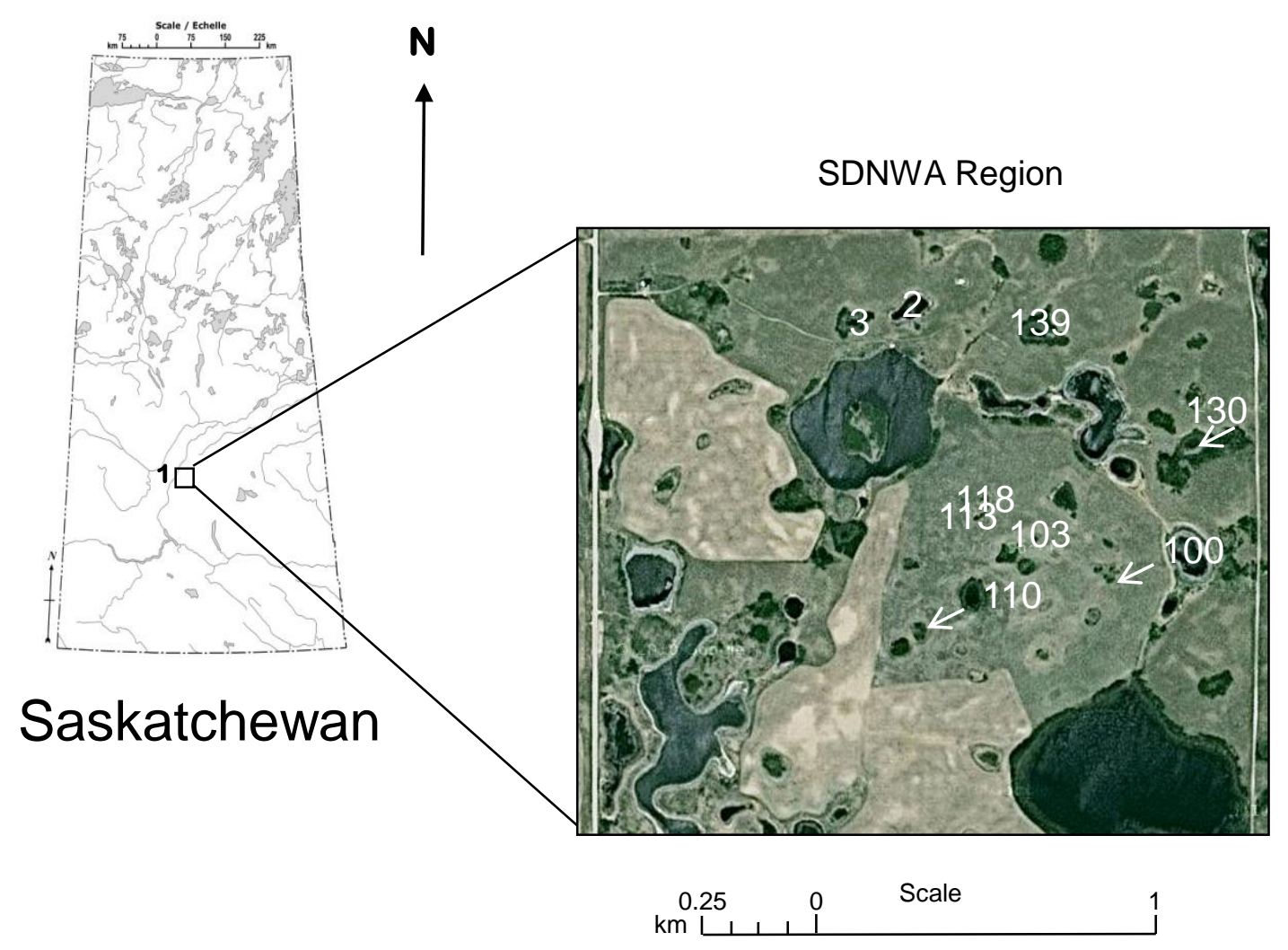

